\title{
IDENTIFIKASI DAN ANALISIS RISIKO OPERASIONAL PADA DIVISI PRODUKSI PERUSAHAAN VULKANISIR BAN MENGGUNAKAN METODE RISK MANAGEMENT DENGAN PENDEKATAN FMEA DAN FTA
}

\author{
Achmad Dahlan $^{1}$, Eko Budi Leksono ${ }^{2}$, dan M. Zainuddin Fathoni ${ }^{3}$ \\ Teknik Industri Universitas Muhammadiyah Gresik \\ Jl. Sumatera No.101, Randuagung, Kec. Gresik, Kabupaten Gresik, Jawa Timur 61121 \\ Email: Achmaddahlan28.ad@gmail.com
}

\begin{abstract}
ABSTRAK
CV.Citra Buana Mandiri merupakan perusahaan manufaktur yang bergerak di bidang vulkanisir ban. Pada divisi produksi CV. Citra Buana Mandiri masih belum optimal dalam mengelola operasional produksinya dikarenakan masih banyak terjadi reject pada hasil produksi ,jeleknya kualitas bahan baku, pekerjaan yang tidak sesuai dengan SOP, dan masih ada kegiatan operasional lain yang terdapat kesalahan dalam pelaksanaannya. Dari permasalahan tersebut dilakukan analisis penyebabnya, kemungkinan risiko yang terjadi, dan solusi untuk memecahkan masalah tersebut. Dalam menentukan variabel proses bisnis, Entitiy, jenis risiko, penyebab risiko, dan penanganan risiko awal dengan cara studi lapangan dan juga brainstorming dengan pihak manajemen perusahaan. Dengan metode Failure Mode and Effect Analysis (FMEA) hasil mode dan effect dibuat kuisioner yang bertujuan untuk memberikan penilaian terhadap risiko, kemudian hasilnya diolah untuk mengetahui Risk Priority Number (RPN) dan risiko kritis yang ada pada divisi produksi. Kemudian dari risiko kritis dicari akar permasalahannya dengan menggunakan metode Fault Tree Analysis (FTA).

Dari hasil FMEA dan FTA diketahui bahwa terdapat 3 entitiy yang memiliki nilai RPN di atas nilai kritis diantaranya risiko dalam Pengelolaan fasilitas dengan 12 basic event, risiko pada kinerja karyawan dengan 9 basic event dan risiko pada proses produksi dengan 16 basic event. Risk treatment Usulan untuk risiko pada entitiy dengan risiko kritis adalah dengan cara mengurangi kemungkinan risiko dan menghindari risiko,untuk Risk response planning pihak manajemen dapat mengambil kebijakan membentuk kepala bagian dalam setiap kegiatan yang menunjang kegiatan divisi produksi, dengan tujuan mempermudah tugas mengelola dan merawat fasilitas, pengawasan kinerja karyawan dan memastikan kualitas hasil produksi.
\end{abstract}

Kata kunci: Divisi produksi, Risk management, Failure Mode and Effect Analysis (FMEA), Fault Tree Analysis (FTA). 


\section{Pendahuluan}

Perkembangan ekonomi dan juga bisnis di indonesia ditambah lagi masuknya Era pasar bebas mengakibatkan persaingan bisnis yang semakin ketat, ini menjadikan perusahaan dituntut bekerja lebih efektif dan juga efisien sehingga perusahaan yang dijalankan bisa terus bertahan dan bersaing dengan kompetitor. Untuk mempertahankan eksistensi dan mengembangkan usaha, setiap perusahaan harus mengestimasi kemungkinan adanya peristiwa atau kejadian baik dari dalam maupun luar perusahaan yang berisiko menghambat rencana dan aktivitas bisnis perusahaan sehingga proses bisnis yang dirancang tidak berjalan sesuai dengan sistem dan pada akhirnya bisa mengancam kelangsungan bisnis yang sedang dijalankan.

CV. Citra Buana Mandiri adalah sebuah perusahaan yang bergerak di bidang jasa dan jual beli ban vulkanisir atau ban bekas yang di daur ulang yaitu melakukan suatu proses terhadap ban yang sudah gundul dengan pemasangan kembali telapak karet yang baru terhadap casing ban sehingga ban tersebut layak untuk digunakan kembali. Untuk itu para pekerja dituntut untuk melakukan proses pengerjaan produksi dengan kehati - hatian.

Pihak manajemen sangat berhati-hati dalam menjalankan operasional perusahaan serta melakukan antisipasi munculnya risiko operasional dalam perusahaan, hal ini terkait dengan ditutupnya salah satu anak perusahaan yang berada di Jakarta disebabkan banyaknya risiko operasinal yang terlambat diantisipasi oleh pihak manajemen serta kurang cekatannya pihak manajemen dalam menangani risiko yang sudah terjadi. Menurut Muslich (2007) risiko operasional merupakan kerugian yang di sebabkan kegagalan proses internal perusahaan, kesalahan sumber daya manusia, kegagalan sistem, kejadian dari luar perusahaan dan pelanggaran peraturan dan hukum yang berlaku.

Berdasarkan hasil studi lapangan atau observasi langsung serta wawancara dengan pihak Manajemen. Diketahui terjadi risiko operasional pada faktor internal divisi produksi. Hal ini dapat di lihat dengan adanya tren kenaikan persentase jumlah reject dari hasil produksi pada periode bulan November 2018 - Februari 2019 yang melebihi target dengan jumlah reject maksimal $3,00 \%$ dari total produksi perbulan. Seperti pada data persentase jumlah reject pada gambar 1

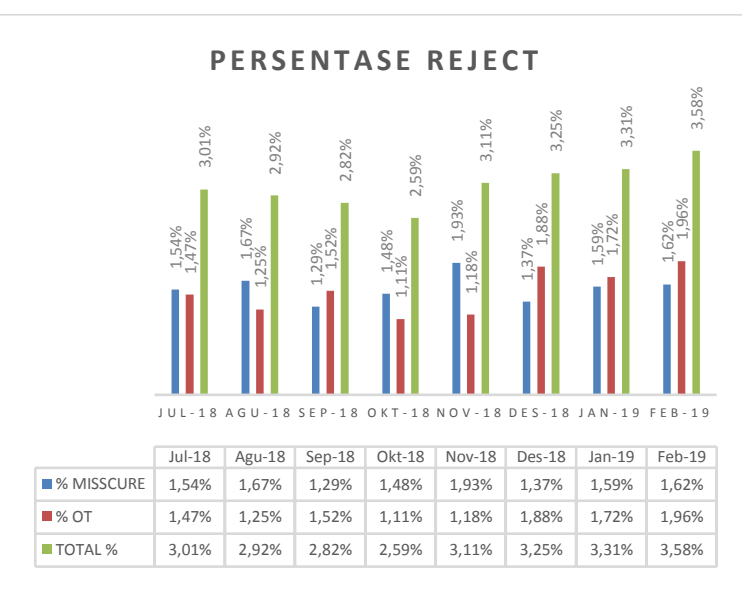

Gambar 1. Data persentase jumlah reject Juli 2018 - Februari 2019

Sumber: CV. Citra Buana Mandiri

Bukan hanya faktor internal yang mempengaruhi adanya risiko operasional pada divisi produksi perusahaan akan tetapi faktor eksternal juga mempengaruhinya, Seperti halnya hubungan dengan divisi lain, kerjasama dengan pihak supplier dan kerjasama dengan pihak customer. Salah satu bentuk adanya risiko operasional yang diakibatkan dari faktor eksternal dapat di lihat pada data persentase jumlah bahan baku ban bekas afkir yang di kirim ke perusahaan.

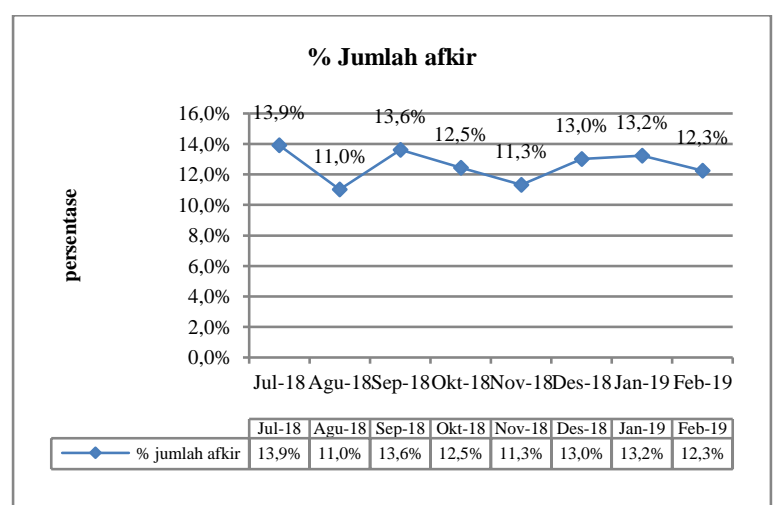

Gambar 2. Data persentase jumlah BB ban bekas afkir Juli 2018 - Februari 2019 Sumber: CV. Citra Buana Mandiri

Ban bekas merupakan bahan baku yang paling vital dalam usaha vulkanisir ban sebab kualitas dari ban bekas akan sangat mempengaruhi kualitas produk yang di hasilkan dari proses produksi. Berdasarkan data pada gambar 1 dan 2, semakin banyak jumlah ban bekas afkir yang di kirim maka probabilitas jumlah reject hasil produksi akan semakin tinggi juga.

Menurut Kristyanto, dkk. (2015) dalam mewujudkan visi dan misi dari perusahaan yang berkaitan dengan daya saing pada dunia industri 
saat ini, maka perlu diperhatikan hal-hal yang berkaitan dengan proses produksi. Jika tahapan dalam proses produksi yang cukup kompleks, hal ini menimbulkan adanya potensi risiko operasional yang cukup tinggi. Risiko-risiko tersebut harus dapat diidentifikasi dan dikelola secara serius untuk terciptanya kestabilan dalam proses produksi. Sehingga untuk mensukseskan usaha perusahaan mengurangi risiko operasional perusahaan harus mengantisipasi kemungkinan adanya peristiwa atau kejadian yang dapat menciptakan risiko operasional. Untuk itu sangat diperlukan sebuah manajemen risiko untuk menjaga agar kegiatan operasional dalam perusahan dapat berjalan sesuai rencana dan tidak menimbulkan risiko yang dapat merugikan perusahaan.

Manajemen risiko pada dasarnya adalah rangkaian proses yang dilakukan untuk meminimalisasi tingkat risiko yang dihadapi sampai pada batas yang dapat diterima, yang merupakan bagian dari corporate governance dan bagian integral dari praktek bisnis yang baik. Risiko yang dihadapi berkaitan dengan keuangan, reputasi, operasional, pasar dan peraturan. Informasi manajemen risiko bermanfaat bagi investor, pemasok, kreditur dan pemegang saham dalam melakukan kerjasama (Susilo \& Kaho, 2017).

Berdasarkan alasan-alasan diatas, penulis menganggap perlu di terapkan analisis Risk Management berbasis ISO 31000 di karenakan adanya faktor internal serta eksternal yang mempengaruhi risiko operasional yang ada pada divisi produksi perusahaan. Dalam penelian ini Failure Mode and Effect Analisys (FMEA) di gunakan sebagai alat untuk menganalisis risiko, serta membuat daftar risiko kritis yang di dapat melalui perhitungan perbandingan total nilai RPN dibagi dengan banyaknya risiko. Langkah selanjutnya menggunakan metode Fault Tree Analysis (FTA) untuk melakukan analisis akar penyebab risiko (Basic Event) dari Top Event yang di dapatkan dari risiko kritis hasil perhitungan nilai RPN . Langkah terakhir adalah membuat risk response planning terhadap setiap risiko kritis sehingga pihak perusahaan diharapkan mampu untuk merencanakan tindakan pencegahan sebelum terjadinya risiko serta dapat menjadi pertimbangan divisi produksi dalam menanggapi risiko.

Tujuan dari penulisan laporan ini adalah sebagai berikut:

1) Mengidentifikasi dan menganalisis unsur - unsur internal dan eksternal pada operasional divisi produksi.

2) Mengidentifikasi dan menganalisis penyebab risiko operasional pada divisi produksi dengan pendekatan Failure Mode and Effect Analisys \& Fault Tree Analisys.

3) Merekomendasikan usulan langkah treatment risiko yang tepat untuk mengantisipasi risiko operasional pada divisi produksi dengan kriteria dari Risk Priority Number.

\section{Tinjauan pustaka}

\subsection{Risiko}

Abisay \& Nurhadi (2013) menjelaskan bahwa risiko adalah efek dari ketidakpastian sasaran. Sedangkan efek ini merupakan penyimpangan dari pengharapan positif dan atau negatif. Sasaran meliputi berbagai aspek seperti finansial, kesehatan dan keselamatan, dan lingkungan. Dengan kata lain risiko merupakan kemungkinan situasi atau keadaan yang dapat mengancam pencapaian tujuan serta sasaran sebuah organisasi atau individu.

\subsection{Risiko operasional}

Menurut Muslich (2007) risiko operasional merupakan risiko atau kerugian yang disebabkan oleh 5 faktor yaitu kegagalan proses internal, kesalahan sumber daya manusia perusahaan, kerusakan atau kesalahan sistem, kerugian yang di sebabkan dari luar perusahaan, dan kerugian karena pelanggaran hukum atau peraturan yang berlaku. Ada beberapa teknik dalam mengidentifikasi risiko operasional antara lain:

1) Risk Self Assessment (RSA) Adalah dimana perusahaan melakukan penilaian sendiri terhadap aktivitas dan operasi perusahaan berdasarkan kejadian risiko.

2) Risk Mapping merupakan suatu proses dimana berbagai unit usaha atau departemen, fungsional organisasi, atau arus proses transaksi yang di-mapping berdasarkan tipe risiko.

3) Key Risk Indicator atau data statistik keuangan yang dapat memberikan gambaran tentang posisi risiko operasional perusahaan.

4) Limit threshold merupakan teknik yang menunjukkan batas kerugian yang dapat di jadikan ukuran toleransi risiko yang dapat di terima.

5) Scorecard merupakan suatu alat untuk mengkonversi penilaian pengelolaan dan pengendalian berbagai aspek kerugian risiko 
operasional yang bersifat kualitatif menjadi perhitungan yang bersifat kuantitatif.

Sedangkan dalam mengidentifikasi risiko operasional, perusahaan harus memperhatikan halhal sebagai berikut:

1) Bersifat proaktif, antisipatif dan bukan reaktif.

2) Harus mencakup seluruh aktifitas fungsional.

3) Menggabungkan dan menganalisis seluruh risiko operasional dari seluruh sumber informasi yang tersedia.

\subsection{Manajemen risiko berbasis ISO 31000}

Manajemen risiko menurut ISO 31000 (2009) adalah aktivitas yang terkoordinasi untuk mengarahkan dan mengendalikan sebuah organisasi dalam menangani risiko. Definisi tersebut memberikan arti mengenai keluasan dan kedalaman sebuah risiko yang menjadi obyek sebuah asesmen.

Menurut Abisay \& Nurhadi (2013) Manajemen risiko merupakan proses iteratif yang terdiri dari langkah-langkah yang terdefinisi yang bertujuan mengidentifikasi dan mengelola risiko dengan baik dan dalam suatu badan usaha akan sangat membantu dalam beberapa hal yaitu:

1) Meramalkan dasar, besarnya serta frekuensi kemungkinan kerugian yang diderita bila terjadi suatu peristiwa yang tidak diduga sebelumnya.

2) Menciptakan suatu dasar untuk mengurangi atau membatasi timbulnya suatu risiko

3) Optimisasi biaya risiko dengan membandingkan biaya yang harus dikeluarkan bila dikelola melalui lembaga asuransi atau dikelola sendiri. Disamping itu bisa dipertimbangkan keuntungan dan kerugian bila risiko tidak dikelola

4) Menyediakan suatu dasar pengambilan keputusan untuk memperkirakan risiko yang mungkin timbul.

Manajemen risiko yang mengacu pada standar ISO 31000 menggambarkan kerangka kerja implementasi manajemen risiko yang dimulai dari identifikasi risiko, analisis risiko dan evaluasi risiko. Tahap-tahap kunci dalam proses direpresentasikan sebagai penilaian risiko, penanganan risiko dan juga menunjukkan bahwa proses manajemen risiko berlangsung dalam konteks risiko manajemen organisasi (Abisay \& Nurhadi, 2013). Kerangka kerja manajemen risiko yang pada dasarnya terdiri dari tiga proses besar dan dua proses yang merupakan pendamping dari ketiga proses besar yang digambarkan secara lebih detail pada gambar 3 .

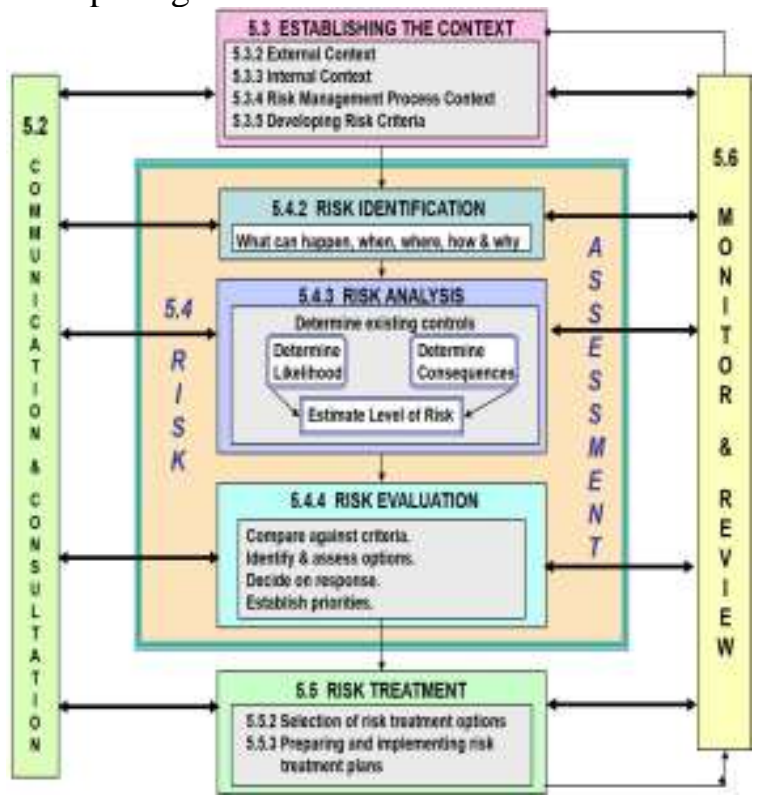

Gambar 3. Kerangka Kerja Manajemen Risiko ISO 31000:2009

Sumber: ISO 31000 (2009:73)

\section{A. Establishing Context}

Penetapan konteks bertujuan untuk mengidentifikasi dan mengungkapkan sasaran organisasi, lingkungan dimana sasaran hendak dicapai, stakeholders yang berkepentingan, dan keberagaman kriteria risiko, dimana hal-hal ini akan membantu mengungkapkan dan menilai sifat dan kompleksitas dari risiko. Beberapa hal yang harus diperhatikan dalam penetapan kontek menurut Susilo \& Kaho (2017)

\section{1) External Context}

Merupakan lingkungan eksternal dimana organisasi melakukan upaya untuk mencapai tujuannya, konteks eksternal dapat meliputi hal hal sebagai berikut (Susilo \& Kaho, 2017):

- Lingkungan sosial, budaya, hukum, politik, ekonomi, keuangan, teknologi, dan keadaan alam baik nasional, regional atau internasional yang mempengaruhi pencapaian organisasi.

- Faktor pendorong dan kecenderungan yang memiliki dampak terhadap tujuan organisasi.

- Nilai - nilai dan persepsi pemangku kepentingan eksternal.

\section{2) Internal Context}

Konteks internal merupakan lingkungan internal di mana organisasi berusaha untuk mencapai tujuannya. Prosedur dalam manajemen risiko harus selaras dengan budaya, prosedur, struktur dan strategi dari organisasi. Konteks internal merupakan segala sesuatu dalam 
organisasi yang dapat mempengaruhi cara organisasi mengelola sebuah risiko (Susilo \& Kaho, 2017).

\section{3) Risk Management Process Context}

Tujuan, strategi, ruang lingkup dan parameter dari kegiatan organisasi, atau bagian-bagian dari organisasi dimana prosedur manajemen risiko yang diterapkan harus ditetapkan. Pengelolaan risiko harus dilakukan dengan penuh pertimbangan kebutuhan dalam mendayagunakan sumber daya yang digunakan dalam melaksanakan manajemen risiko. Sumber daya yang diperlukan, tanggung jawab dan wewenang, dan catatan untuk disimpan juga harus ditetapkan. Konteks dari prosedur manajemen risiko akan bervariasi sesuai dengan kebutuhan organisasi.

\section{4) Developing Risk Criteria}

Organisasi harus menetapkan kriteria yang akan digunakan untuk mengevaluasi signifikansi risiko. Kriteria harus dapat mencerminkan nilainilai organisasi, tujuan dan sumber daya. Beberapa kriteria yang dapat dikenakan oleh, atau berasal dari, persyaratan hukum, peraturan dan persyaratan lainnya yang diterapkan oleh organisasi. Kriteria risiko harus konsisten dengan kebijakan manajemen risiko organisasi, yang didefinisikan pada awal setiap prosedur manajemen risiko dan akan terus ditinjau.

B. Risk Assessment

Risk assessment (Penilaian risiko) terdiri dari:

\section{1) Risk Identification:}

Tujuan dari risk identification (penilaian risiko) adalah untuk mengidentifikasi sebuah risiko yang harus dikelola oleh sebuah organisasi melalui proses yang terstruktur dan sistematis. Sedangkan sasaran dari penilaian risiko adalah mengembangkan daftar sumber dari risiko dan kejadian yang komprehensif serta mempunyai dampak terhadap tujuan dan target yang teridentifikasi dari sebuah konteks (Susilo \& Kaho, 2017).

Metode yang di gunakan tergantung pada proses penentuan konteks agar terjadi kesinambungan sehingga tidak terjadi kerancuan dalam keseluruhan proses identifikasi risiko. Sementara metode-metode yang di gunakan untuk memperdalam proses identifikasi risiko diantaranya (Susilo \& Kaho, 2017):

$>$ Pengujian dokumen (document review)

$>$ Analisis pemangku kepentingan (stakeholder analys)

Risk Breakdown structure (RBS)
Metode penentuan proses bisnis (business process mapping)

2) Risk Analysis

Risk analysis (Analisis risiko) merupakan upaya untuk dapat memahami sebuah risiko lebih dalam dan hasilnya akan menjadi sebuah masukan dalam evaluasi risiko serta pengambilan keputusan dalam perlakuan terhadap risiko. Sedangkan tujuan dari analisis risiko adalah melakukan analisis dampak dan kemungkinan seluruh risiko yang mampu menghambat terwujudnya tujuan dari organisasi (Susilo \& Kaho, 2017)

Secara umum untuk menentukan besarnya angka kemungkinan antara lain: (Susilo \& Kaho, 2017).

a) Jika sedikit sekali atau tidak ada data tersedia :

a. Subjective probability,

b. Uniform distribution probability.

c. Probability matrix, merupakan tabel yang berisi tentang uraian kemungkinan dalam bentuk kuantitatif atau kualitatif dengan di lenglapi dengan sebutannya,

b) Apabila di masa lalu terdapat data yang dimiliki cukup banyak mengenai risikorisiko yang sudah terjadi bisa di buat model matematika dan pola distribusinya.

Pada tahap analisis risiko terdapat tahap penentuan risiko yang menjadi prioritas untuk di tangani yang dapat di lakukan dengan menggunakan risk score atau dengan penentuan risiko kritis berdasarkan nilai RPN. Dalam penentuan nilai batas risiko sehingga di tetapkan sebagai risiko kritis dapat di buat secara klasifikasi rendah, sedang dan tinggi atau di tentukan secara umum. Akan tetapi penentuan klasifikasi atau nilai batas penanganan risiko di tentukan oleh manajemen atau kepala tim. (Susilo \& Kaho, 2017)

\section{3) Risk Evaluation}

Risk Evaluation (Evaluasi risiko) memiliki tujuan untuk membantu dalam proses pengambilan sebuah keputusan yang di dasrkan pada hasil analisis risiko. Akan tetapi analisis risiko juga dapat menghasilkan sebuah keputusan hanya dengan tetap mempertahankan pengendalian risiko yang sudah ada atau hanya denagan memperkuat penegendalian risiko tersebut.

C. Penanganan risiko (risk treatment)

Secara umum terdapat empat cara dalam melakukan perlakuan dalam menangani sebuah 
risiko antara lain (Susilo \& kaho 2017):

1) Menghindari risiko (risk avoidance). Merupakan strategi untuk meniadakan sepenuhnya risiko dengan cara tidak melakukan kegiatan yang sudah di perkirakan mempunyai risiko.

2) Berbagi risiko / Transfer risiko kepada pihak lain (risk sharing / risk transfer) adalah suatu tindakan strtegi yang digunakan untuk memindahkan sebagian dari sebuah risiko kepada individu, entitas bisnis, atau organisasi lain.

3) Mengurangi kemungkinan atau dampak dari risiko (risk mitigation)

4) Menerima risiko (risk acceptance) strategi ini dilakukan bila tidak ada langkah / alternative lain yang bisa dilakukan untuk menghindari risiko atau memang dianggap lebih ekonomis jika menerapkannya.

\section{Communication \& Consultation}

Merupakan hal yang penting mengingat prinsip manajemen risiko yang kesembilan menuntut manajemen risiko yang transparan dan inklusif, dimana manajemen risiko harus dilakukan oleh seluruh bagian organisasi dan memperhitungkan kepentingan dari seluruh Stakeholders organisasi.

\section{E. Monitoring \& Review}

Hal ini diperlukan untuk memastikan bahwa implementasi manajemen risiko telah berjalan sesuai dengan perencanaan yang dilakukan. Hasil monitoring dan review juga dapat digunakan sebagai bahan pertimbangan untuk melakukan perbaikan terhadap proses manajemen risiko.

\subsection{Failure Mode and Effect Analysis (FMEA)}

FMEA adalah suatu prosedur terstruktur untuk mengidentifikasi dan mencegah sebanyak mungkin mode kegagalan (failure mode). FMEA digunakan untuk mengidentifikasi sumbersumber dan akar penyebab dari suatu masalah kualitas. Failure Mode and Effect Analysis (FMEA) menerapkan suatu metode pentabelan untuk membantu proses pemikiran yang digunakan oleh engginer untuk mengidentifikasi mode kegagalan potensial dan efeknya. FMEA merupakan teknik evaluasi tingkat keandalan dari sebuah sistem untuk menentukan efek dari kegagalan dari sistem tersebut. Fokus perhatian diutamakan pada bentuk kegagalan yang ada. Bentuk kegagalan dapat didefinisikan sebagai setiap peristiwa yang mungkin dapat menyebabkan model (sistem atau proses) mengalami kegagalan. Cara yang tepat adalah untuk menunjukkan hubungan dan perbedaan antara kegagalan fungsi terlebih dahulu, lalu mencatat bentuk kegagalan yang disebabkan oleh kegagalan fungsi (Gaspersz, 2002). (2002)

Tahapan - tahapan FMEA menurut Gasperz

1) Melakukan pengamatan terhadap proses.

2) Mengidentifikasi potensial failure mode dari proses yang diamati.

3) Mengidentifikasi akibat (potensial effect) yang ditimbulkan potensi failure mode.

4) Menetapkan nilai severity (S) merupakan penilaian seberapa serius efek failure mode.

5) Mengidentifikasi penyebab risiko (Potential Risk Cause) dari failure mode pada proses yang berlangsung.

6) Menetapkan nilai occurance (O), occurrence menunjukkan nilai keseringan / frekuensi suatu masalah yang terjadi karena potencial cause.

7) Mengidentifikasi kontrol proses saat ini (current process control) yang merupakan deskripsi dari kontrol untuk mencegah kemungkinan suatu yang menyebabkan mode kegagalan.

8) Menetapkan nilai detection (D), dimana detection menggambarkan seberapa mampu proses kontrol selama ini untuk mendeteksi ataupun pencegah terjadinya mode kegagalan.

9) Menentukan nilai risk priority number (RPN) dengan cara mengalikan nilai severity (S) occurance $(\mathrm{O})$, detection (D). RPN = $\mathrm{S} * \mathrm{O} * \mathrm{D}$. Nilai RPN menunjukkan keseriusan dari potential failure.

10)Memberikan usulan perbaikan (recommended action) terhadap potential cause, alat kontrol dan efek yang diakibatkan. Prioritas perbaikan pada failure mode yang memiliki RPN tertinggi dan seterusnya.

\subsection{Fault Tree Analisys (FTA)}

Metode ini dilakukan dengan pendekatan yang bersifat top down, yang diawali dengan asumsi kegagalan dari kejadian puncak (Top Event) kemudian merinci sebab-sebab suatu Top Event sampai pada suatu kegagalan dasar (root cause). Sedangkan dalam pengertian lain FTA adalah salah satu teknik yang diandalkan, dimana kegagalan yang tidak diinginkan di atur dengan cara menarik kesimpulan dan di paparkan dalam gambar atau sebuah tool grafis yang melakukan pencatatan semua mode kesalahan dari sebuah 
sistem yang rumit menjadi kombinasi logika, hubungan sederhana gerbang AND dan OR (Ansori \& Mustajib, 2013).

Pada mulanya, dengan kejadian TOP dan menuju ke kejadian mula, konstruksi Fault Tree adalah satu proses yang dapat digunakan untuk menarik kesimpulan. Sedabgkan fungsi dari Fault Tree Analysis adalah diagram yang digunakan untuk mendeteksi adanya gejala supaya mengetahui akar penyebab suatu masalah, dimulai dari kejadian puncak (Ansori \& Mustajib, 2013).

Menurut Ansori \& Mustajib (2013) langkahlangkah utama dalam FTA adalah sebagai berikut:

1) Definisi dari sistem, TOP event dan batasan masalah.

2) Pembuatan FTA (Fault Tree Analysis)

3) Identifikasi kemungkinan

4) Analisa Kuatitatif

5) Analisa kuantitatif

6) Pelaporan (Report)

Dalam FTA terdapat dua macam bangunan balok yaitu simbol pintu dan simbol kejadian (Ansori \& Mustajib, 2013)

1) Simbol Pintu (Gate Sysmbol) menghubungkan kejadian - kejadian sesuai dengan hubungannya yang menyangkut sebab.

a) Pintu "DAN" adalah satu kejadian keluar terjadi, jika dan hanya jika semua masukan terjadi.

b) Pintu "ATAU" adalah kejadian keluar terjadi jika satu atau lebih masukan terjadi.

c) Pintu "TRANSFER" adalah symbol menyediakan satu alat guna mencegah pengulangan bagian dari Fault Tree.

2) Simbol Kejadian (Event Symbol )

a) Lingkaran mewakili satu kejadian kesalahan dasar yang tidak memerlukan pemeriksaan lebih lanjut.

b) Belah Ketupat mewakili kejadian kesalahan yaitu yang diduga mendasar dalam satu Fault Tree.

c) Segi empat / panjang mewakili kejadian sebagai hasil dari kombinasi dari macam kejadian yang di uraikan di atas melalui masukan dari pintu yang sesuai.

\subsection{Gerbang Logika}

A. Gerbang AND

Gerbang AND digunakan untuk menghasilkan logika 1 jika semua masukan berlogika 1, jika tidak maka output yang dihasilkan akan berlogika 0 (Siregar dan Parinduri, 2017).

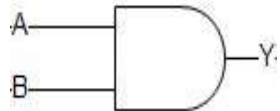

Gambar 4. Simbol kebenaran AND

Tabel 1. Tabel Kebenaran AND

\begin{tabular}{|l|l|l|}
\hline \multicolumn{2}{|l|}{ INPUT } & OUTPUT \\
\hline A & B & Y \\
\hline 0 & 0 & 0 \\
\hline 0 & 1 & 0 \\
\hline 1 & 0 & 0 \\
\hline 1 & 1 & 1 \\
\hline
\end{tabular}

B. Gerbang OR

Gerbang OR digunakan untuk menghasilkan logika 0 jika semua masukan berlogika 0 , jika tidak maka output yang dihasilkan akan berlogika 1 (Siregar dan Parinduri, 2017).

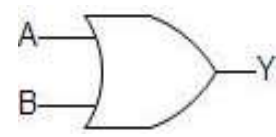

Gambar 5. Simbol kebenaran OR

Tabel 2. Tabel Kebenaran OR

\begin{tabular}{|l|l|l|}
\hline \multicolumn{2}{|l|}{ INPUT } & OUTPUT \\
\hline A & B & Y \\
\hline 0 & 0 & 0 \\
\hline 0 & 1 & 1 \\
\hline 1 & 0 & 1 \\
\hline 1 & 1 & 1 \\
\hline
\end{tabular}

\section{Metodologi penelitian}

Langkah dalam penelitian merupakan suatu gambaran sistematis yang akan dijadikan sebagai acuan dalam melakukan sebuah peneltian. Gambar 6 di bawah ini merupakan langkah-langkah yang dilakukan pada penelitian yang dilakukan pada divisi produksi perusahaan. 


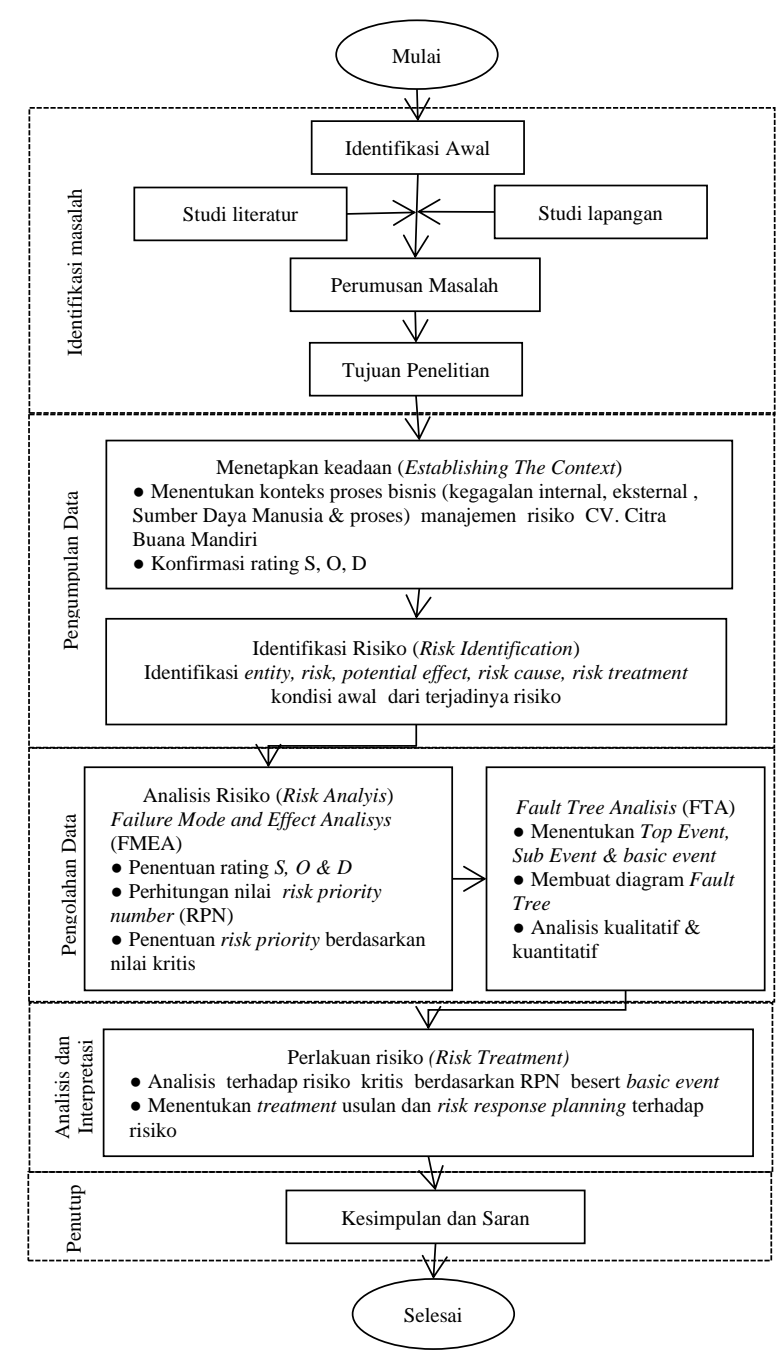

Gambar 6. Flowchart Metodologi penelitian

\section{Hasil dan Pembahasan}

\subsection{Pengumpulan Data}

\section{A. Menetapkan Konteks (Estabilishing the Context)}

Penetapan konteks diperoleh melalui wawancara dan brainstorming kepada responden dari pihak manajemen perusahaan. Responden den dalam penetian ini diantaranya general manajer, kepala bagian produksi, karyawan produksi dan staf gudang.

Dipilihnya empat responden diatas dikarenakan mereka dianggap mengerti secara langsung jenis-jenis risiko yang dapat mempengaruhi divisi produksi dan juga sebagai pemangku risiko.

Penetapan konteks yang di susun sesuai dengan ruang lingkup divisi produksi sehingga menghasilkan konteks yang secara umum terbagi menjadi empat kegagalan proses bisnis yaitu kegagalan proses, kegagalan internal, kegagalan eksternal, dan kegagalan manusia. Sementara
Entitiy risiko disusun melalui breakdown dari setiap risiko proses bisnis berdasarkan kegiatan operasional pada proses bisnis tersebut.

Penetapan konteks ini di gunakan sebagai sarana untuk mengetahui potensi terjadinya sebuah risiko serta dampak dan penanganan yang sudah dilakukan oleh manajemen pada divisi produksi. Penetapan konteks yang disetujui pihak responden di jelaskan pada tabel 3 di bawah ini.

Tabel 3. Konteks risiko operasional divisi produksi

\begin{tabular}{|c|c|c|}
\hline \multicolumn{3}{|c|}{ Risiko Operasional Divisi Produksi } \\
\hline No. & Proses bisnis & Entitiy \\
\hline \multirow{2}{*}{1} & \multirow{2}{*}{ Kegagalan internal } & Pengelolaan fasilitas \\
\hline & & Pengembangan teknologi \\
\hline \multirow{3}{*}{2} & \multirow{3}{*}{ Kegagalan eksternal } & Customer relation \\
\hline & & Supplier relation \\
\hline & & $\begin{array}{l}\text { Hubungan dengan Manajemen } \\
\text { perusahaan }\end{array}$ \\
\hline \multirow{2}{*}{3} & \multirow{2}{*}{ Kegagalan human } & Kinerja karyawan \\
\hline & & Pengelolaan SDM \\
\hline \multirow{2}{*}{4} & \multirow{2}{*}{ kegagalan proses } & Proses produksi \\
\hline & & Sirkulasi bahan baku \\
\hline
\end{tabular}

\section{B. Konfirmasi Kriteria \& Level Risiko}

Konfirmasi kriteria risiko unuk menentukan level risiko kepada pihak manajemen perusahaan dilakukan dengan membuat skala masing-masing untuk nilai severity, occurance \& detection yang akan di gunakan sebagai acuan dalam melakukan penilaian terhadap risiko yang sesuai dengan kondisi yang ada dalam divisi produksi. Berikut ini adalah level risiko yang telah disetujui oleh pihak manajemen

Tabel 4. Konfirmasi level Risiko Severity

\begin{tabular}{|c|l|}
\hline Rating & \multicolumn{1}{|c|}{ Kriteria } \\
\hline 1 & $\begin{array}{l}\text { Negliable severity (pengaruh buruk yang dapat diabaikan). Kita } \\
\text { tidak perlu memikirkan bahwa akibat ini akan berdampak pada } \\
\text { kinerja produk. }\end{array}$ \\
\hline 2 & $\begin{array}{l}\text { Mild severity (pengaruh buruk yang ringan/sedikit). Akibat yang } \\
\text { ditimbulkan hanya bersifat ringan. Pengguna akhir tidak akan } \\
\text { merasakan kinerja. }\end{array}$ \\
\hline 4 & $\begin{array}{l}\text { Moderate severity (pengaruh buruk yang moderat). Pengguna } \\
\text { akhir akan merasakan penurunan kinerja atau penampilan, } \\
\text { namun masih berada dalam batas toleransi. }\end{array}$ \\
\hline 7 & $\begin{array}{l}\text { High severity (pengaruh burukyang tinggi). Pengguna akhir akan } \\
\text { merasakan akibat buruk yang tidak dapat diterima, berada diluar } \\
\text { batas toleransi. Akibat akan terjadi tanpa pemberitahuan atau } \\
\text { peringatan terlebih dahulu. }\end{array}$ \\
\hline 9 & $\begin{array}{l}\text { Potential safety problem (masalah keselamatan/keamanan } \\
\text { potensial). Akibat yang ditimbulkan sangat berbahaya yang } \\
\text { dapat terjadi tanpa pemberitahuan atau peringatan terlebih } \\
\text { dahulu. }\end{array}$ \\
\hline 10
\end{tabular}

Sumber: Gaspersz (2002)

Tabel 5. Konfirmasi level Risiko Occurance

\begin{tabular}{|c|c|c|}
\hline Rating & \multicolumn{1}{|c|}{ Kriteria verbal } & Tingkat kegagalan \\
\hline 1 & $\begin{array}{l}\text { Adalah tidak mungkin bahwa penyebab } \\
\text { ini mengangkibatkan mode kegagalan }\end{array}$ & 1 dalam 1.000 .000 \\
\hline 2 & \multirow{2}{*}{ Kegagalan akan jarang terjadi } & 1 dalam 20.000 \\
\hline 3 & & 1 dalam 4.000 \\
\hline 4 & \multirow{2}{*}{ Kegagalan akan mungkin terjadi } & 1 dalam 1.000 \\
\cline { 3 - 3 } 5 & & 1 dalam 400 \\
\hline
\end{tabular}




\begin{tabular}{|c|l|l|}
\hline 6 & & 1 dalam 80 \\
\hline 7 & \multirow{2}{*}{ Kegagalan akan sangat mungkin terjadi } & 1 dalam 40 \\
\cline { 3 - 3 } & & 1 dalam 20 \\
\hline 9 & \multirow{2}{*}{$\begin{array}{l}\text { Hampir dipastikan bahwa kegagalan } \\
\text { akan terjadi }\end{array}$} & 1 dalam 8 \\
\cline { 3 - 3 } & 1 dalam 2 \\
\hline 10 & &
\end{tabular}

Sumber: Gaspersz (2002)

Tabel 6. Konfirmasi level Risiko Detection

\begin{tabular}{|c|l|l|}
\hline Rating & \multicolumn{1}{|c|}{ Kriteria verbal } & \multicolumn{1}{|c|}{$\begin{array}{c}\text { Tingkat } \\
\text { kejadian }\end{array}$} \\
\hline 1 & $\begin{array}{l}\text { Metode pencegahan atau deteksi sangat efektif } \\
\text { tidak ada kesempatan bahwa penyebab } \\
\text { mungkin masih muncul atau terjadi }\end{array}$ & $\begin{array}{l}1 \text { dalam } \\
1.000 .000\end{array}$ \\
\hline 2 & $\begin{array}{l}\text { Kemungkinan bahwa penyebab itu terjadi } \\
\text { adalah rendah }\end{array}$ & $\begin{array}{l}1 \text { dalam } \\
20.000 \\
1 \text { dalam } \\
4.000\end{array}$ \\
\hline 4 & $\begin{array}{l}\text { Kemungkinan penyebab terjadi bersifat } \\
\text { moderat. Metode pencegahan atau deteksi }\end{array}$ & 1 dalam \\
1.000 \\
1 dalam \\
400 \\
6 & $\begin{array}{l}\text { masih memungkinkan kadang-kadang penyebab } \\
\text { itu terjadi }\end{array}$ & 1 dalam 80 \\
\hline 7 & $\begin{array}{l}\text { Kemungkinan bahwa penyebab itu terjadi masih } \\
\text { tinggi. Metode pencegahan atau deteksi kurang }\end{array}$ & 1 dalam 20 \\
\hline 8 & $\begin{array}{l}\text { efektif, karena penyebab masih berulang } \\
\text { kembali. }\end{array}$ & 1 dalam 8 \\
\hline 9 & $\begin{array}{l}\text { Kemungkinan bahwa penyebab itu terjadi } \\
\text { sangat tinggi metode pencegahan atau deteksi }\end{array}$ & 1 dalam 2 \\
\hline 10 & $\begin{array}{l}\text { tidak efektif. Penyebab akan selalu terjadi } \\
\text { kembali. }\end{array}$ & \\
\hline
\end{tabular}

Severity (S), Occurane (O) \& Detection (D) dengan skala 1 sampai 10 karena disesuaikan dengan keadaan yang ada serta tujuan di lakukannya penelitian ini, yaitu mengatasi risiko operasional pada divisi produksi.

\section{Identifikasi Risiko (Risk identification)}

Pada tahap ini di lakukan proses identifkasi risiko yang meliputi sumber risiko, dampak risiko, peristiwa yang terjadi, penyebab risiko dan potensi yang diakibatkan melalui pengembangan dari $5 \mathrm{~W}$ $1 \mathrm{H}$ ( what, where, who, why \& how ) dengan cara melakukan wawancara dan brainstorming kepada responden yaitu General Manager, kepala bagianproduksi, staff gudang dan karyawan produksi. Pada tahap ini dilakukan juga penelitian mengenai ruang lingkup proses bisnis, mode kegagalan, potensi dampak risiko (potential effect), penyebab yang berpotensi menimbulkan sebuah risiko (Potential Risk Cause). Ruang lingkup proses identifikasi risiko pada divisi produksi dapat di lihat pada tabel 7 di bawah ini.

Sumber: Gaspersz (2002)

Digunakannya Konfirmasi risiko nilai

Tabel 7. Identifikasi risiko pada divisi produksi

\begin{tabular}{|c|c|c|c|c|c|c|}
\hline Proses bisnis & Entitiy & ID & Risk & Potential effects & Risk Cause & Treatment awal \\
\hline \multirow{9}{*}{$\begin{array}{c}\text { kegagalan } \\
\text { internal }\end{array}$} & \multirow{6}{*}{$\begin{array}{l}\text { Pengelolaan } \\
\text { fasilitas }\end{array}$} & R1 & $\begin{array}{l}\text { Kapasitas gudang tidak } \\
\text { mampu menampung barang } \\
\text { yang ada }\end{array}$ & $\begin{array}{l}\text { Bahan baku di taruh di luar gudang } \\
\text { sehingga terkontaminasi kotoran / } \\
\text { air hujan }\end{array}$ & $\begin{array}{l}\text { Ukurang gudang tidak luas dan } \\
\text { penataan barangyang buruk }\end{array}$ & $\begin{array}{l}\text { Menempatkan sebagian bahan } \\
\text { baku ke lokasi produksi }\end{array}$ \\
\hline & & R2 & $\begin{array}{l}\text { Kerusakan pada mesin } \\
\text { kompressor sehingga tekanan } \\
\text { angin melemah }\end{array}$ & Mesin tidak bisa berjalan optimal & $\begin{array}{l}\text { Tidak adanya jadwal khusus } \\
\text { perawatan mesin kompressor }\end{array}$ & $\begin{array}{l}\text { Melakukan pengecekan kondisi } \\
\text { mesin kompresor setiap hari }\end{array}$ \\
\hline & & R3 & $\begin{array}{l}\text { Lampu penerang redup / } \\
\text { padam }\end{array}$ & $\begin{array}{l}\text { Tidak dapat mendeteksi cacat pada } \\
\text { ban }\end{array}$ & Kualiatas lampu penerangan buruk & $\begin{array}{l}\text { Mengganti lampu yang sudah } \\
\text { redup dengan lampu yang baru }\end{array}$ \\
\hline & & R4 & $\begin{array}{l}\text { Jumlah dan kapasitas mesin } \\
\text { minim }\end{array}$ & Tidak terpenuhinya target produksi & $\begin{array}{l}\text { Tidak adanya dana untuk menambah } \\
\text { mesin }\end{array}$ & Menambah jam lembur \\
\hline & & R5 & $\begin{array}{l}\text { AC dalam gudang tread dan } \\
\text { gum rusak }\end{array}$ & $\begin{array}{l}\text { Kualitas tread dan gum menjadi } \\
\text { jelek dan kemungkinan rusak tidak } \\
\text { dapat di gunakan untuk produksi }\end{array}$ & Kualitas AC mulai menurun & $\begin{array}{l}\text { Melakukan pengecekan suhu } \\
\text { ruangan dan juga AC secara } \\
\text { berkala }\end{array}$ \\
\hline & & R6 & Listrik tiba-tiba padam & $\begin{array}{l}\text { Hasil produksi tidak bisa matang } \\
\text { sempurna }\end{array}$ & $\begin{array}{l}\text { Kurangnya pengecekan instalasi } \\
\text { listrik }\end{array}$ & $\begin{array}{l}\text { Mengecek kondisi intalasi listrik } \\
\text { sekitar area kerja sebelum } \\
\text { melakukan pekerjaan }\end{array}$ \\
\hline & \multirow{3}{*}{$\begin{array}{l}\text { Pengembangan } \\
\text { teknologi }\end{array}$} & R7 & $\begin{array}{l}\text { Kesalahan input data } \\
\text { spesifikasi produk yang di } \\
\text { minta customer }\end{array}$ & $\begin{array}{l}\text { Produk yang di produksi tidak } \\
\text { sesuai permintaan customer }\end{array}$ & $\begin{array}{l}\text { Tidak adanya pengecekan ulang } \\
\text { sebelum melakukan produksi }\end{array}$ & $\begin{array}{l}\text { Kabag produksi keliling } \\
\text { mengecek kesesuaian data } \\
\text { dengan produk yang di produksi }\end{array}$ \\
\hline & & R8 & $\begin{array}{l}\text { Mesin sering mengalami } \\
\text { kerusakan }\end{array}$ & $\begin{array}{l}\text { Tidak mampu memenuhi jumlah } \\
\text { target produksi }\end{array}$ & Usia mesin sudah diatas 20 tahun & $\begin{array}{l}\text { Melakukan perawatan serta } \\
\text { mengganti spare part yang sudah } \\
\text { aus atau rusak }\end{array}$ \\
\hline & & R9 & Data base produksi hilang & $\begin{array}{l}\text { Hilangnya data hasil produksi dan } \\
\text { jumlah permintaan customer }\end{array}$ & Tidak melakukan back up data & $\begin{array}{l}\text { Kabag produksi membuat dan } \\
\text { merekap laporan harian secara } \\
\text { manual }\end{array}$ \\
\hline \multirow{12}{*}{$\begin{array}{c}\text { Kegagalan } \\
\text { eksternal }\end{array}$} & \multirow{6}{*}{ Supplier relation } & R10 & $\begin{array}{l}\text { Terdapat ozon pada tread } \\
\text { yang datang }\end{array}$ & Terjadi reject pada hasil produksi & $\begin{array}{l}\text { Pengiriman tread tidak menggunakan } \\
\text { container berpendingin }\end{array}$ & $\begin{array}{l}\text { Komunikasi dengan supplier } \\
\text { untuk pengadaan alat } \\
\text { transportasinya }\end{array}$ \\
\hline & & R11 & $\begin{array}{l}\text { Terjadi perselisihan dengan } \\
\text { supplier }\end{array}$ & $\begin{array}{l}\text { Penundaan pengiriman bahan baku } \\
\text { sehingga produksi harus berhenti } \\
\text { sementara }\end{array}$ & $\begin{array}{l}\text { Buruknya komunikasi dengan pihak } \\
\text { supplier }\end{array}$ & $\begin{array}{l}\text { Menambah intensitas } \\
\text { komunikasi dengan supplier }\end{array}$ \\
\hline & & $\mathrm{R} 12$ & Kenaikan harga bahan baku & $\begin{array}{l}\text { Beban biaya perusahaan } \\
\text { bertambah }\end{array}$ & Kenaikan harga karet mentah & $\begin{array}{l}\text { Menaikkan harga jual produk } \\
\text { jadi }\end{array}$ \\
\hline & & R13 & $\begin{array}{l}\text { Pembatalan kontrak kerja } \\
\text { sepihak }\end{array}$ & $\begin{array}{l}\text { Bahan baku tidak jadi dikirim } \\
\text { sehingga stok habis dan tidak bisa } \\
\text { melakukan kegiatan produksi }\end{array}$ & Supplier kecewa terhadap manajemen & $\begin{array}{l}\text { Mencari supplier lain yang } \\
\text { menjual jenis produk yang sama }\end{array}$ \\
\hline & & R14 & Kekeliruan pengiriman barang & $\begin{array}{l}\text { Tidak dapat melakukan proses } \\
\text { produksi sesuai rencana }\end{array}$ & $\begin{array}{l}\text { Tidak ada penegecekan ulang } \\
\text { sebelum barang di kirim }\end{array}$ & $\begin{array}{l}\text { Melakukan evaluasi kerja secara } \\
\text { tegas dengan pihak supplier }\end{array}$ \\
\hline & & R15 & $\begin{array}{l}\text { Kualitas bahan baku yang di } \\
\text { kirim tidak sesuai standart } \\
\text { yang di inginkan perusahaan }\end{array}$ & $\begin{array}{l}\text { Jika di lanjut ke proses produksi, } \\
\text { kemungkinan besar produk reject }\end{array}$ & $\begin{array}{l}\text { Supplier tidak melakukan inspeksi } \\
\text { sebelum barang di kirim }\end{array}$ & $\begin{array}{l}\text { Melakukan inspeksi saat barang } \\
\text { datang sehingga bisa di return ke } \\
\text { pihak supplier }\end{array}$ \\
\hline & \multirow{5}{*}{$\begin{array}{l}\text { Customer } \\
\text { relation }\end{array}$} & R16 & $\begin{array}{l}\text { Kepercayaan terhadap } \\
\text { perusahaan menurun }\end{array}$ & $\begin{array}{l}\text { Jumlah permintaan yang masuk } \\
\text { sedikit }\end{array}$ & $\begin{array}{l}\text { Rendahnya kualitas produk yang di } \\
\text { hasilkan }\end{array}$ & $\begin{array}{l}\text { Melakukan komunikasi dengan } \\
\text { customer secara intens dan } \\
\text { memberikan garansi }\end{array}$ \\
\hline & & R17 & $\begin{array}{l}\text { Meminta harga lebih rendah } \\
\text { dari biasanya }\end{array}$ & $\begin{array}{l}\text { Keuntungan yang di dapat } \\
\text { berkurang }\end{array}$ & $\begin{array}{l}\text { Adanya pesaing dengan harga yang } \\
\text { lebih murah }\end{array}$ & $\begin{array}{l}\text { Menberikan garansi kualitas } \\
\text { produk }\end{array}$ \\
\hline & & $\mathrm{R} 18$ & Pembatalan pesanan & Jumlah produksi berkurang & Kekecewaan terhadap kualitas produk & Mencari customer lain \\
\hline & & R19 & $\begin{array}{l}\text { Jumlah order yang di minta } \\
\text { bertambah sedikit }\end{array}$ & Banyak pekerja mengangur & $\begin{array}{l}\begin{array}{l}\text { Sales tidak pandai memasarkan } \\
\text { produk }\end{array} \\
\end{array}$ & Meniadakan sistem kerja lembur \\
\hline & & R20 & $\begin{array}{l}\text { Komplain terhadap produk } \\
\text { yang sudah di kirim }\end{array}$ & $\begin{array}{l}\text { Produk yang sudah di kirim di } \\
\text { kembalikan oleh customer }\end{array}$ & $\begin{array}{l}\text { Kualitas produk tidak sesuai } \\
\text { permintaan customer }\end{array}$ & $\begin{array}{l}\text { Mengganti dengan produk yang } \\
\text { baru atau me rework produk } \\
\text { yang jelek }\end{array}$ \\
\hline & $\begin{array}{l}\text { Manajemen } \\
\text { perusahaan }\end{array}$ & $\mathrm{R} 21$ & $\begin{array}{l}\text { Menggunakan bahan baku } \\
\text { lokal dengan kualitas rendah }\end{array}$ & $\begin{array}{l}\text { Kualitas produk yang di hasilkan } \\
\text { jelek }\end{array}$ & $\begin{array}{l}\text { Naiknya harga bahan baku import } \\
\text { karena Nilai tukar dollar terhadap } \\
\text { rupiah semakin tinggi }\end{array}$ & $\begin{array}{l}\text { Mencari supplier lokal yang } \\
\text { memiliki kualitas produk } \\
\text { minnimal sama }\end{array}$ \\
\hline
\end{tabular}




\begin{tabular}{|c|c|c|c|c|c|c|}
\hline & & R22 & Pengurangan jam kerja lembur & $\begin{array}{l}\text { Target jumlah produksi bulanan } \\
\text { tidak tercapai }\end{array}$ & $\begin{array}{l}\text { Beban biaya untuk gaji karyawan } \\
\text { bertambah karena kenaikan upah } \\
\text { mininum pekerja }\end{array}$ & $\begin{array}{l}\text { Meminimalisir jumlah waktu } \\
\text { lembur }\end{array}$ \\
\hline & & R23 & $\begin{array}{l}\text { Perbedaan data hasil produksi } \\
\text { antara manajemen dengan } \\
\text { divisi produksi }\end{array}$ & Terganggunya kegiatan produksi & $\begin{array}{l}\text { Ada miss komunikasi antara } \\
\text { manajeman dengan divisi produksi }\end{array}$ & $\begin{array}{l}\text { Kabag produksi melakukan } \\
\text { pencatatan manual laporan } \\
\text { produksi harian }\end{array}$ \\
\hline \multirow{8}{*}{$\begin{array}{l}\text { Kegagalan } \\
\text { human }\end{array}$} & \multirow{5}{*}{$\begin{array}{c}\text { Kinerja } \\
\text { karyawan }\end{array}$} & R24 & $\begin{array}{l}\text { Salah dalam pemberian label } \\
\text { produksi }\end{array}$ & $\begin{array}{l}\text { Hasil produksi tidak sesuai } \\
\text { keinginan customer }\end{array}$ & $\begin{array}{l}\text { Pekerja tidak melakukan pengecekan } \\
\text { label pada produk sebelum di proses }\end{array}$ & $\begin{array}{l}\text { Instruksi kepada karyawan } \\
\text { inspeksi untuk melakukan } \\
\text { malakukan pengecekan label } \\
\text { produksi }\end{array}$ \\
\hline & & R25 & $\begin{array}{l}\text { Tidak menambal cacat lubang } \\
\text { pada bodi ban }\end{array}$ & $\begin{array}{l}\text { Kebocoran pada hasil produk } \\
\text { (reject) }\end{array}$ & $\begin{array}{l}\text { Pekerja kurang teliti dalam } \\
\text { melakukan inspeksi produk }\end{array}$ & $\begin{array}{l}\text { Instruksi pada karyawan bagian } \\
\text { building untuk melakukan } \\
\text { pengecekan kebocoran ban }\end{array}$ \\
\hline & & R26 & $\begin{array}{l}\text { Salah dalam memberi tanda } \\
\text { cacat }\end{array}$ & $\begin{array}{l}\text { Cacat tidak di tangani dengan } \\
\text { semestinya }\end{array}$ & $\begin{array}{l}\text { Ketidak pahaman pekerja tentang } \\
\text { ketentuan penanandaan pada cacat }\end{array}$ & $\begin{array}{l}\text { Instruksi kepada bagian repair } \\
\text { untuk cek ulang kondisi ban }\end{array}$ \\
\hline & & R27 & $\begin{array}{l}\text { Karyawan tidak melakukan } \\
\text { pekerjaan sesuai SOP }\end{array}$ & $\begin{array}{l}\text { Hasil produksi tidak sesuai } \\
\text { standart yang di tetapkan } \\
\text { perusahaan }\end{array}$ & $\begin{array}{l}\text { Kurangnya training tentang SOP yang } \\
\text { di berikan kepada kayawan dan tidak } \\
\text { adanya form SOP di setiap stasiun } \\
\text { kerja }\end{array}$ & $\begin{array}{l}\text { Memberikan training kepada } \\
\text { karyawan sesuai dengan jobdisk }\end{array}$ \\
\hline & & $\mathrm{R} 28$ & Keterbatasan skill karyawan & Adanya kegagalan proses produksi & $\begin{array}{l}\text { Kurangnya training yang di berikan } \\
\text { kepada kayawan }\end{array}$ & $\begin{array}{l}\text { Memberikan training kepada } \\
\text { karyawan }\end{array}$ \\
\hline & \multirow{3}{*}{$\begin{array}{l}\text { Pengelolaan } \\
\text { SDM }\end{array}$} & R29 & $\begin{array}{l}\text { Karyawan meninggalkan } \\
\text { tempat saat jam kerja }\end{array}$ & Terganggunya kegiatan produksi & $\begin{array}{l}\text { Tidak adanya teguran dari kepala } \\
\text { produksi }\end{array}$ & $\begin{array}{l}\text { Pengawasan terhadap karyawan } \\
\text { saat jam kerja }\end{array}$ \\
\hline & & R30 & Tidak adanya divisi kualitas & $\begin{array}{l}\text { Kualitas tidak terkontrol dengan } \\
\text { baik }\end{array}$ & Kurangnya jumlah karyawan & $\begin{array}{l}\text { Kabag gudang \& produksi } \\
\text { berperan melakukan pengecekan } \\
\text { kualitas }\end{array}$ \\
\hline & & R31 & $\begin{array}{l}\text { Kurangnya kuantitas } \\
\text { karyawan produksi }\end{array}$ & $\begin{array}{l}\text { Tidak dapat mencapai target } \\
\text { produksi yang di tentukan }\end{array}$ & $\begin{array}{l}\text { Adanya pekerja yang tidak masuk } \\
\text { kerja }\end{array}$ & $\begin{array}{l}\text { Memberikan peringatan bagi } \\
\text { karyawan yang absen tanpa } \\
\text { sebab }\end{array}$ \\
\hline
\end{tabular}

Tabel 7. Identifikasi risiko pada divisi produksi (lanjutan)

\begin{tabular}{|c|c|c|c|c|c|c|}
\hline $\begin{array}{l}\text { Proses } \\
\text { bisnis }\end{array}$ & Entitiy & ID & Risk & Potential effects & Risk Cause & Treatment awal \\
\hline \multirow{7}{*}{$\begin{array}{c}\text { kegagalan } \\
\text { proses }\end{array}$} & \multirow{5}{*}{$\begin{array}{l}\text { Proses } \\
\text { produksi }\end{array}$} & R32 & $\begin{array}{l}\text { Tread tidak dapat merekat } \\
\text { sempurna dengan body ban }\end{array}$ & $\begin{array}{l}\text { Produk reject harus melalui } \\
\text { proses rework }\end{array}$ & Kualitas chuisen gum jelek & $\begin{array}{l}\text { Pengecekan kualitas chuisen gum sebelum } \\
\text { di gunakan }\end{array}$ \\
\hline & & R33 & $\begin{array}{l}\text { Terjadi kerusakan pada mesin } \\
\text { saat proses produksi }\end{array}$ & $\begin{array}{l}\text { Terjadi banyak idle / tidak } \\
\text { dapat melakukan proses } \\
\text { produksi }\end{array}$ & Usia mesin yang sudah diatas 20 tahun & $\begin{array}{l}\text { Melakukan pelumasan sebelum memulai } \\
\text { kerja dan memperbaiki mesin jika rusak }\end{array}$ \\
\hline & & R34 & Envelope bocor & $\begin{array}{l}\text { Terjadi cacat kembung } \\
\text { sehingga barang } \text { reject }\end{array}$ & $\begin{array}{l}\text { Kualitas envelope sudah tidak sesuai } \\
\text { standart }\end{array}$ & $\begin{array}{l}\text { Melakukan pengecekan kondisi envolope } \\
\text { sebelum di gunakan }\end{array}$ \\
\hline & & R35 & Ban dalam bocor & $\begin{array}{l}\text { Terjadi cacat kembung } \\
\text { sehingga barang reject }\end{array}$ & $\begin{array}{l}\text { Kualitas ban dalam sudah tidak sesuai } \\
\text { standart }\end{array}$ & $\begin{array}{l}\text { Melakukan pengecekan kondisi ban dalam } \\
\text { sebelum di gunakan }\end{array}$ \\
\hline & & R36 & $\begin{array}{l}\text { Hasil produksi tidak bisa } \\
\text { matang sempurna }\end{array}$ & Produk reject & Suhu chamber tidak stabil & $\begin{array}{l}\text { Melakukan pengecekan kondisi chamber } \\
\text { sebelum memasukkan produk dan setelah } \\
\text { mengeluarkan produk dari chamber }\end{array}$ \\
\hline & \multirow{2}{*}{$\begin{array}{c}\text { Sirkulasi } \\
\text { bahan baku }\end{array}$} & R37 & $\begin{array}{l}\text { Terdapat bahan baku yang } \\
\text { rusak tidak dapat di pakai } \\
\text { karena terlalu lama di gudang }\end{array}$ & $\begin{array}{l}\text { Kerugian finansial karena } \\
\text { bahan baku tidak dapat di } \\
\text { gunakan }\end{array}$ & $\begin{array}{l}\text { Tidak menggunakan sistem first in first } \\
\text { out karena tidak ada SOP yang } \\
\text { mengharuskan melakukan sisten FIFO }\end{array}$ & $\begin{array}{l}\text { Kepala bagian produksi dan gudang } \\
\text { bekerja sama melakukan check stock } \\
\text { opname }\end{array}$ \\
\hline & & R38 & $\begin{array}{l}\text { Tidak melakukan pencatatan } \\
\text { saat pengambilan bahan baku }\end{array}$ & $\begin{array}{l}\text { Terjadi selisih perhitungan } \\
\text { jumlah bahan baku yang } \\
\text { tersedia di gudang }\end{array}$ & $\begin{array}{l}\text { Kelalaian pegawai produksi yang } \\
\text { mengambil barang ke gudang }\end{array}$ & $\begin{array}{l}\text { Melakukan perhitungan dan pencocokan } \\
\text { data produksi dan stock gudang }\end{array}$ \\
\hline
\end{tabular}

Pada tahap identifikasi risiko dapat di ketahui bahwa terdapat 38 jenis risiko yang terdapat di divisi produksi dengan enam risiko pada pengelolaan fasilitas, tiga risiko pada pengembangan teknologi, enam risiko pada supplier relation, lima risiko pada customer relation, tiga risiko pada manajemen perusahaan, lima risiko pada kinerja karyawan, tiga risiko pada pengelolaan SDM, dan lima risiko pada proses produksi.

\subsection{Pengolahan Data}

Pada tahap pengolahan data ini di lakukan analisis risiko dengan menggunakan 2 tahap. Tahap pertama menggunakan Failure Mode and Effect Analisys (FMEA) dan tahap ke dua menggunakan Fault Tree Analisys (FTA).

\section{A. Analisis risiko menggunakan metode FMEA}

Dalam penelian ini Failure Mode and Effect Analisys (FMEA) di gunakan sebagai alat untuk menganalisis risiko, serta membuat daftar risiko kritis berdasarkan nilai risk priority number (RPN) yang di dapat melalui perhitungan perkalian nilai severity (S), occurance (O) \& detection (D) berdasarkan identifikasi risiko dan juga kriteria risiko yang sudah dikonfirmasi oleh pihak manajemen. Setelah diketahui nilai RPN setiap risiko langkah selanjutnya menhitung rata-rata nilai RPN dari setiap Entitiy yang di dapat dari jumlah nilai S, O, D dari Entity dibagi jumlah risiko (risk) untuk menentukan risiko kritis dari Entity. Nilai rata-rata tersebut digunakan untuk menentukan risk priority untuk melakukan eliminasi risiko yang memiliki nilai rata-rata RPN di bawah nilai kritis untuk di jadikan top event pada proses FTA.

Nilai risk priority number sendiri akan menjadi masukan dalam melakukan evaluasi terhadap risiko dan juga sebagai masukan pada proses pengambilan keputusan dalam melakukan perlakuan terhadap risiko. Pengisian nilai severity, occurance \& detection di peroleh dengan cara penyebaran kuisoner dan juga brainstorming kepada responden dari pihak manajemen 
perusahaan. Analisis risiko menggunakan FMEA akan di sajikan lebih jelas dalam tabel 8 .

Tabel 8. Analisis Risiko Divisi Produksi

\begin{tabular}{|c|c|c|c|c|c|c|c|c|c|c|}
\hline $\begin{array}{c}\text { Proses } \\
\text { bisnis }\end{array}$ & Entitiy & ID & Risk & Potential effects & $S$ & Risk Cause & $o$ & Treatment awal & $D$ & RPN \\
\hline \multirow{11}{*}{$\begin{array}{c}\text { Kegagalan } \\
\text { internal }\end{array}$} & \multirow{7}{*}{$\begin{array}{l}\text { Pengelolaan } \\
\text { fasilitas }\end{array}$} & R1 & $\begin{array}{l}\text { Kapasitas gudang tidak } \\
\text { mampu menampung } \\
\text { barang yang ada }\end{array}$ & $\begin{array}{l}\text { Bahan baku di taruh di luar gudang } \\
\text { sehingga terkontaminasi kotoran / } \\
\text { air hujan }\end{array}$ & 7 & $\begin{array}{l}\text { Ukuran gudang tidak } \\
\text { luas dan penataan } \\
\text { barangyang buruk }\end{array}$ & 7 & $\begin{array}{l}\text { Menempatkan sebagian bahan } \\
\text { baku ke lokasi produksi }\end{array}$ & 5 & 245 \\
\hline & & R2 & $\begin{array}{l}\text { Kerusakan pada mesin } \\
\text { kompressor sehingga } \\
\text { tekanan angin melemah }\end{array}$ & Mesin tidak bisa berjalan optimal & 7 & $\begin{array}{l}\text { Tidak adanya jadwal } \\
\text { khusus perawatan mesin } \\
\text { kompressor }\end{array}$ & 6 & $\begin{array}{l}\text { Melakukan pengecekan kondisi } \\
\text { mesin kompresor setiap hari }\end{array}$ & 5 & 210 \\
\hline & & R3 & $\begin{array}{l}\text { Lampu penerang redup / } \\
\text { padam }\end{array}$ & $\begin{array}{l}\text { Tidak dapat mendeteksi cacat pada } \\
\text { ban }\end{array}$ & 8 & $\begin{array}{l}\text { Kualiatas lampu } \\
\text { penerangan buruk }\end{array}$ & 7 & $\begin{array}{l}\text { Mengganti lampu yang sudah } \\
\text { redup dengan lampu yang baru }\end{array}$ & 5 & 280 \\
\hline & & R4 & $\begin{array}{l}\text { Jumlah dan kapasitas } \\
\text { mesin minim }\end{array}$ & Tidak terpenuhinya target produksi & 8 & $\begin{array}{l}\text { Tidak adanya dana } \\
\text { untuk menambah mesin }\end{array}$ & 8 & Menambah jam lembur & 5 & 320 \\
\hline & & R5 & $\begin{array}{l}\text { AC dalam gudang tread } \\
\text { dan gum rusak }\end{array}$ & $\begin{array}{l}\text { Kualitas tread dan gum menjadi } \\
\text { jelek dan kemungkinan rusak tidak } \\
\text { dapat di gunakan untuk produksi }\end{array}$ & 5 & $\begin{array}{l}\text { Kualitas AC mulai } \\
\text { menurun }\end{array}$ & 5 & $\begin{array}{l}\text { Melakukan pengecekan suhu } \\
\text { ruangan dan juga AC secara } \\
\text { berkala }\end{array}$ & 5 & 125 \\
\hline & & R6 & Listrik tiba-tiba padam & $\begin{array}{l}\text { Hasil produksi tidak bisa matang } \\
\text { sempurna }\end{array}$ & 8 & $\begin{array}{l}\text { Kurangnya pengecekan } \\
\text { instalasi listrik }\end{array}$ & 7 & $\begin{array}{l}\text { Mengecek kondisi intalasi } \\
\text { listrik sekitar area kerja } \\
\text { sebelum melakukan pekerjaan }\end{array}$ & 4 & 224 \\
\hline & & \multicolumn{3}{|c|}{ RATA-RATA } & 7,2 & & 6,7 & & 4,8 & 230,9 \\
\hline & \multirow{4}{*}{$\begin{array}{c}\text { Pengembangan } \\
\text { teknologi }\end{array}$} & R7 & $\begin{array}{l}\text { Kesalahan input data } \\
\text { spesifikasi produk yang di } \\
\text { minta customer }\end{array}$ & $\begin{array}{l}\text { Produk yang di produksi tidak } \\
\text { sesuai permintaan customer }\end{array}$ & 4 & $\begin{array}{l}\text { Tidak adanya } \\
\text { pengecekan ulang } \\
\text { sebelum melakukan } \\
\text { produksi }\end{array}$ & 5 & $\begin{array}{l}\text { Kabag produksi keliling } \\
\text { mengecek kesesuaian data } \\
\text { dengan produk yang di } \\
\text { produksi }\end{array}$ & 4 & 80 \\
\hline & & R8 & $\begin{array}{l}\text { Mesin sering mengalami } \\
\text { kerusakan }\end{array}$ & $\begin{array}{l}\text { Tidak mampu memenuhi jumlah } \\
\text { target produksi }\end{array}$ & 6 & $\begin{array}{l}\text { Usia mesin sudah diatas } \\
20 \text { tahun }\end{array}$ & 4 & $\begin{array}{l}\text { Melakukan perawatan serta } \\
\text { mengganti spare part yang } \\
\text { sudah aus atau rusak }\end{array}$ & 6 & 144 \\
\hline & & R9 & Data base produksi hilang & $\begin{array}{l}\text { Hilangnya data hasil produksi dan } \\
\text { jumlah permintaan customer }\end{array}$ & 4 & $\begin{array}{l}\text { Tidak melakukan back } \\
\text { up data }\end{array}$ & 4 & $\begin{array}{l}\text { Kabag produksi membuat dan } \\
\text { merekap laporan harian secara } \\
\text { manual }\end{array}$ & 4 & 64 \\
\hline & & \multicolumn{3}{|c|}{ RATA-RATA } & 4,7 & & 4,3 & & 4,7 & 94,37 \\
\hline
\end{tabular}

Tabel 8. Analisis Risiko Divisi Produksi (lanjutan)

\begin{tabular}{|c|c|c|c|c|c|c|c|c|c|c|}
\hline $\begin{array}{c}\text { Proses } \\
\text { bisnis }\end{array}$ & Entitiy & ID & Risk & Potential effects & $s$ & Risk Cause & $o$ & Treatment awal & $D$ & RPN \\
\hline \multirow{16}{*}{$\begin{array}{c}\text { kegagalan } \\
\text { eksternal }\end{array}$} & \multirow{7}{*}{$\begin{array}{l}\text { supplier } \\
\text { relation }\end{array}$} & R10 & $\begin{array}{l}\text { Terdapat ozon pada tread } \\
\text { yang datang }\end{array}$ & $\begin{array}{l}\text { Terjadi reject pada hasil } \\
\text { produksi }\end{array}$ & 6 & $\begin{array}{l}\text { Pengiriman tread tidak } \\
\text { menggunakan container } \\
\text { berpendingin }\end{array}$ & 5 & $\begin{array}{l}\text { Berkomunikasi dengan supplier } \\
\text { untuk pengadaan alat } \\
\text { transportasinya }\end{array}$ & 4 & 120 \\
\hline & & R11 & $\begin{array}{l}\text { Terjadi perselisihan } \\
\text { dengan supplier }\end{array}$ & $\begin{array}{l}\text { Penundaan pengiriman } \\
\text { bahan baku sehingga } \\
\text { produksi harus berhenti } \\
\text { sementara }\end{array}$ & 4 & $\begin{array}{l}\text { Buruknya komunikasi dengan } \\
\text { pihak supplier }\end{array}$ & 5 & $\begin{array}{l}\text { Menambah intensitas komunikasi } \\
\text { dengan supplier }\end{array}$ & 4 & 80 \\
\hline & & R12 & $\begin{array}{l}\begin{array}{l}\text { Kenaikan harga bahan } \\
\text { baku }\end{array} \\
\end{array}$ & $\begin{array}{l}\text { Beban biaya perusahaan } \\
\text { bertambah }\end{array}$ & 6 & Kenaikan harga karet mentah & 7 & Menaikkan harga jual produk jadi & 5 & 210 \\
\hline & & R13 & $\begin{array}{l}\text { Pembatalan kontrak kerja } \\
\text { sepihak }\end{array}$ & $\begin{array}{l}\text { Bahan baku tidak jadi } \\
\text { dikirim sehingga stok habis } \\
\text { dan tidak bisa melakukan } \\
\text { kegiatan produksi } \\
\end{array}$ & 7 & $\begin{array}{l}\text { Supplier kecewa terhadap } \\
\text { manajemen }\end{array}$ & 5 & $\begin{array}{l}\text { Mencari supplier lain yang } \\
\text { menjual jenis produk yang sama }\end{array}$ & 5 & 175 \\
\hline & & R14 & $\begin{array}{l}\text { Kekeliruan pengiriman } \\
\text { barang }\end{array}$ & $\begin{array}{l}\text { Tidak dapat melakukan } \\
\text { proses produksi sesuai } \\
\text { rencana }\end{array}$ & 5 & $\begin{array}{l}\text { Tidak ada penegecekan ulang } \\
\text { sebelum barang di kirim }\end{array}$ & 5 & $\begin{array}{l}\text { Melakukan evaluasi kerja secara } \\
\text { tegas dengan pihak supplier }\end{array}$ & 4 & 100 \\
\hline & & R15 & $\begin{array}{l}\text { Kualitas bahan baku yang } \\
\text { di kirim tidak sesuai } \\
\text { standart yang di inginkan } \\
\text { perusahaan }\end{array}$ & $\begin{array}{l}\text { Jika di lanjut ke proses } \\
\text { produksi, kemungkinan } \\
\text { besar produk reject }\end{array}$ & 5 & $\begin{array}{l}\text { Supplier tidak melakukan } \\
\text { inspeksi sebelum barang di } \\
\text { kirim }\end{array}$ & 8 & $\begin{array}{l}\text { Melakukan inspeksi saat barang } \\
\text { datang sehingga bisa di return ke } \\
\text { pihak supplier }\end{array}$ & 5 & 200 \\
\hline & & \multicolumn{3}{|c|}{ RATA-RATA } & 5,5 & & 5,8 & & 4,5 & 144,4 \\
\hline & \multirow{6}{*}{$\begin{array}{l}\text { customer } \\
\text { relation }\end{array}$} & R16 & $\begin{array}{l}\text { Kepercayaan terhadap } \\
\text { perusahaan menurun }\end{array}$ & $\begin{array}{l}\text { Jumlah permintaan yang } \\
\text { masuk sedikit }\end{array}$ & 6 & $\begin{array}{l}\text { Rendahnya kualitas produk yang } \\
\text { di hasilkan }\end{array}$ & 5 & $\begin{array}{l}\text { Melakukan komunikasi dengan } \\
\text { customer secara intens dan } \\
\text { memberikan garansi }\end{array}$ & 6 & 180 \\
\hline & & R17 & $\begin{array}{l}\text { Meminta harga lebih } \\
\text { rendah dari biasanya }\end{array}$ & $\begin{array}{l}\text { Keuntungan yang di dapat } \\
\text { berkurang }\end{array}$ & 5 & $\begin{array}{l}\text { Adanya pesaing dengan harga } \\
\text { yang lebih murah }\end{array}$ & 6 & $\begin{array}{l}\text { Menberikan garansi kualitas } \\
\text { produk }\end{array}$ & 5 & 150 \\
\hline & & R18 & Pembatalan pesanan & Jumlah produksi berkurang & 6 & $\begin{array}{l}\text { Kekecewaan terhadap kualitas } \\
\text { produk }\end{array}$ & 4 & Mencari customer lain & 6 & 144 \\
\hline & & R19 & $\begin{array}{l}\text { Jumlah order yang di } \\
\text { minta bertambah sedikit }\end{array}$ & Banyak pekerja mengangur & 4 & $\begin{array}{l}\text { Sales tidak pandai memasarkan } \\
\text { produk }\end{array}$ & 5 & Meniadakan sistem kerja lembur & 4 & 80 \\
\hline & & R20 & $\begin{array}{l}\text { Komplain terhadap produk } \\
\text { yang sudah di kirim }\end{array}$ & $\begin{array}{l}\text { Produk yang sudah di kirim } \\
\text { di kembalikan oleh } \\
\text { customer }\end{array}$ & 6 & $\begin{array}{l}\text { Kualitas produk tidak sesuai } \\
\text { permintaan customer }\end{array}$ & 5 & $\begin{array}{l}\text { Mengganti dengan produk yang } \\
\text { baru atau me rework produk yang } \\
\text { jelek }\end{array}$ & 6 & 180 \\
\hline & & \multicolumn{3}{|c|}{ RATA-RATA } & 5,4 & & 5 & & 5,4 & 145,8 \\
\hline & & R21 & $\begin{array}{l}\text { Menggunakan bahan baku } \\
\text { lokal dengan kualitas } \\
\text { rendah }\end{array}$ & $\begin{array}{l}\text { Kualitas produk yang di } \\
\text { hasilkan jelek }\end{array}$ & 6 & $\begin{array}{l}\text { Naiknya harga bahan baku } \\
\text { import karena Nilai tukar dollar } \\
\text { terhadap rupiah semakin tinggi }\end{array}$ & 7 & $\begin{array}{l}\text { Mencari supplier lokal yang } \\
\text { memiliki kualitas produk } \\
\text { minnimal sama }\end{array}$ & 6 & 252 \\
\hline & $\begin{array}{l}\text { manajemen } \\
\text { perusahaan }\end{array}$ & R22 & $\begin{array}{l}\text { Pengurangan jam kerja } \\
\text { lembur }\end{array}$ & $\begin{array}{l}\text { Target jumlah produksi } \\
\text { bulanan tidak tercapai }\end{array}$ & 5 & $\begin{array}{l}\text { Beban biaya untuk gaji } \\
\text { karyawan bertambah karena } \\
\text { kenaikan upah mininum pekerja } \\
\end{array}$ & 5 & $\begin{array}{l}\text { Meminimalisir jumlah waktu } \\
\text { lembur }\end{array}$ & 5 & 125 \\
\hline & & R23 & $\begin{array}{l}\text { Perbedaan data hasil } \\
\text { produksi antara } \\
\text { manajemen dengan divisi } \\
\text { produksi }\end{array}$ & $\begin{array}{l}\text { Terganggunya kegiatan } \\
\text { produksi }\end{array}$ & 5 & $\begin{array}{l}\text { Ada miss komunikasi antara } \\
\text { manajeman dengan divisi } \\
\text { produksi }\end{array}$ & 5 & $\begin{array}{l}\text { Kabag produksi melakukan } \\
\text { pencatatan manual laporan } \\
\text { produksi harian }\end{array}$ & 3 & 75 \\
\hline \multirow{9}{*}{$\begin{array}{c}\text { Kegagalan } \\
\text { human }\end{array}$} & \multirow{6}{*}{$\begin{array}{c}\text { Kinerja } \\
\text { karyawan }\end{array}$} & R24 & $\begin{array}{l}\text { Salah dalam pemberian } \\
\text { label produksi }\end{array}$ & $\begin{array}{l}\text { Hasil produksi tidak sesuai } \\
\text { keinginan customer }\end{array}$ & 6 & $\begin{array}{l}\text { Pekerja tidak melakukan } \\
\text { pengecekan label pada produk } \\
\text { sebelum di proses }\end{array}$ & 5 & $\begin{array}{l}\text { Instruksi kepada karyawan } \\
\text { inspeksi untuk melakukan } \\
\text { malakukan pengecekan label } \\
\text { produksi }\end{array}$ & 5 & 150 \\
\hline & & R25 & $\begin{array}{l}\text { Tidak menambal cacat } \\
\text { lubang pada bodi ban }\end{array}$ & $\begin{array}{l}\text { Kebocoran pada hasil } \\
\text { produk (reject) }\end{array}$ & 7 & $\begin{array}{l}\text { Pekerja kurang teliti dalam } \\
\text { melakukan inspeksi produk }\end{array}$ & 6 & $\begin{array}{l}\text { Instruksi pada karyawan bagian } \\
\text { building untuk melakukan } \\
\text { pengecekan kebocoran ban }\end{array}$ & 5 & 210 \\
\hline & & R26 & $\begin{array}{l}\text { salah dalam memberi } \\
\text { tanda cacat }\end{array}$ & $\begin{array}{l}\text { Cacat tidak di tangani } \\
\text { dengan semestinya }\end{array}$ & 8 & $\begin{array}{l}\text { Ketidak pahaman pekerja } \\
\text { tentang ketentuan penanandaan } \\
\text { pada cacat }\end{array}$ & 6 & $\begin{array}{l}\text { Instruksi kepada bagian repair } \\
\text { untuk cek ulang kondisi ban }\end{array}$ & 5 & 240 \\
\hline & & R27 & $\begin{array}{l}\text { Karyawan tidak } \\
\text { melakukan pekerjaan } \\
\text { sesuai SOP }\end{array}$ & $\begin{array}{l}\text { Hasil produksi tidak sesuai } \\
\text { standart yang di tetapkan } \\
\text { perusahaan }\end{array}$ & 7 & $\begin{array}{l}\text { Kurangnya training tentang SOP } \\
\text { yang di berikan kepada kayawan } \\
\text { dan tidak adanya form SOP di } \\
\text { setiap stasiun kerja }\end{array}$ & 6 & $\begin{array}{l}\text { Memberikan training kepada } \\
\text { karyawan }\end{array}$ & 5 & 210 \\
\hline & & R28 & $\begin{array}{l}\begin{array}{l}\text { Keterbatasan skill } \\
\text { karyawan }\end{array} \\
\end{array}$ & $\begin{array}{l}\text { Adanya kegagalan proses } \\
\text { produksi }\end{array}$ & 6 & $\begin{array}{l}\text { Kurangnya training yang di } \\
\text { berikan kepada kayawan }\end{array}$ & 6 & $\begin{array}{l}\text { Memberikan training kepada } \\
\text { karyawan sesuai dengan jobdesk }\end{array}$ & 5 & 180 \\
\hline & & \multicolumn{3}{|c|}{ RATA-RATA } & 6,8 & & 5,8 & & 5 & 197,2 \\
\hline & \multirow{3}{*}{$\begin{array}{l}\text { Pengelolaan } \\
\text { SDM }\end{array}$} & R29 & $\begin{array}{l}\text { Karyawan meninggalkan } \\
\text { tempat saat jam kerja }\end{array}$ & $\begin{array}{l}\text { Terganggunya kegiatan } \\
\text { produksi }\end{array}$ & 4 & $\begin{array}{l}\text { Tidak adanya teguran dari } \\
\text { kepala produksi }\end{array}$ & 6 & $\begin{array}{l}\text { Pengawasan terhadap karyawan } \\
\text { saat jam kerja }\end{array}$ & 4 & 96 \\
\hline & & R30 & $\begin{array}{l}\text { Tidak adanya divisi } \\
\text { kualitas }\end{array}$ & $\begin{array}{l}\text { Kualitas tidak terkontrol } \\
\text { dengan baik }\end{array}$ & 7 & Kurangnya jumlah karyawan & 7 & $\begin{array}{l}\text { Kabag gudang \& produksi } \\
\text { berperan melakukan pengecekan } \\
\text { kualitas }\end{array}$ & 5 & 245 \\
\hline & & R31 & $\begin{array}{l}\text { Kurangnya kuantitas } \\
\text { karyawan produksi }\end{array}$ & $\begin{array}{l}\text { Tidak dapat mencapai target } \\
\text { produksi yang di tentukan }\end{array}$ & 5 & $\begin{array}{l}\text { Adanya pekerja yang tidak } \\
\text { masuk kerja }\end{array}$ & 7 & $\begin{array}{l}\text { Memberikan peringatan bagi } \\
\text { karyawan yang absen tanpa sebab }\end{array}$ & 3 & 105 \\
\hline
\end{tabular}




\begin{tabular}{|c|c|c|c|c|c|c|c|c|c|c|}
\hline & & \multicolumn{3}{|c|}{ RATA-RATA } & \multirow{2}{*}{$\frac{5,3}{7}$} & \multirow[b]{2}{*}{ Kualitas chuisen gum jelek } & \multirow{2}{*}{$\frac{6,7}{7}$} & \multirow[b]{2}{*}{$\begin{array}{l}\text { Pengecekan kualitas chuisen gum } \\
\text { sebelum di gunakan }\end{array}$} & \multirow{2}{*}{4} & \multirow{2}{*}{$\frac{142,2}{245}$} \\
\hline \multirow{9}{*}{$\begin{array}{c}\text { Kegagalan } \\
\text { proses }\end{array}$} & \multirow{6}{*}{$\begin{array}{c}\text { Proses } \\
\text { produksi }\end{array}$} & R32 & $\begin{array}{l}\text { Tread tidak dapat merekat } \\
\text { sempurna dengan body } \\
\text { ban }\end{array}$ & $\begin{array}{l}\text { Produk reject harus melalui } \\
\text { proses rework }\end{array}$ & & & & & & \\
\hline & & R33 & $\begin{array}{l}\text { Terjadi kerusakan mesin } \\
\text { pada saat proses produksi }\end{array}$ & $\begin{array}{l}\text { Terjadi banyak idle / tidak } \\
\text { dapat melakukan proses } \\
\text { produksi }\end{array}$ & 7 & $\begin{array}{l}\text { Usia mesin yang sudah diatas } 20 \\
\text { tahun }\end{array}$ & 5 & $\begin{array}{l}\text { Melakukan pelumasan sebelum } \\
\text { memulai kerja dan memperbaiki } \\
\text { mesin jika rusak }\end{array}$ & 5 & 175 \\
\hline & & R34 & Envelope bocor & $\begin{array}{l}\text { Terjadi cacat kembung } \\
\text { sehingga barang reject }\end{array}$ & 6 & $\begin{array}{l}\text { Kualitas envelope sudah tidak } \\
\text { sesuai standart }\end{array}$ & 6 & $\begin{array}{l}\text { Melakukan pengecekan kondisi } \\
\text { envolope sebelum di gunakan }\end{array}$ & 5 & 180 \\
\hline & & R35 & Ban dalam bocor & $\begin{array}{l}\text { Terjadi cacat kembung } \\
\text { sehingga barang reject }\end{array}$ & 6 & $\begin{array}{l}\text { Kualitas ban dalam sudah tidak } \\
\text { sesuai standart }\end{array}$ & 6 & $\begin{array}{l}\text { Melakukan pengecekan kondisi } \\
\text { ban dalam sebelum di gunakan }\end{array}$ & 5 & 180 \\
\hline & & R36 & $\begin{array}{l}\text { Hasil produksi tidak bisa } \\
\text { matang sempurna }\end{array}$ & produk reject & 8 & Suhu chamber tidak stabil & 8 & $\begin{array}{l}\text { Melakukan pengecekan kondisi } \\
\text { chamber sebelum memasukkan } \\
\text { produk dan setelah mengeluarkan } \\
\text { produk dari chamber }\end{array}$ & 5 & 320 \\
\hline & & \multicolumn{3}{|c|}{ RATA-RATA } & 6,8 & & 6,4 & & 5 & 217.6 \\
\hline & \multirow{3}{*}{$\begin{array}{c}\text { Sirkulasi } \\
\text { bahan baku }\end{array}$} & R37 & $\begin{array}{l}\text { Terdapat bahan baku yang } \\
\text { rusak tidak dapat di pakai } \\
\text { karena terlalu lama di } \\
\text { gudang }\end{array}$ & $\begin{array}{l}\text { Kerugian finansial karena } \\
\text { bahan baku tidak dapat di } \\
\text { gunakan }\end{array}$ & 6 & $\begin{array}{l}\text { Tidak menggunakan sistem first } \\
\text { in first out karena tidak ada SOP } \\
\text { yang mengharuskan melakukan } \\
\text { sisten FIFO }\end{array}$ & 5 & $\begin{array}{l}\text { Kepala bagian produksi dan } \\
\text { gudang bekerja sama melakukan } \\
\text { check stock opname }\end{array}$ & 5 & 150 \\
\hline & & R38 & $\begin{array}{l}\text { Tidak melakukan } \\
\text { pencatatan saat } \\
\text { pengambilan bahan baku }\end{array}$ & $\begin{array}{l}\text { Terjadi selisih perhitungan } \\
\text { jumlah bahan baku yang } \\
\text { tersedia di gudang }\end{array}$ & 4 & $\begin{array}{l}\text { Kelalaian pegawai produksi } \\
\text { yang mengambil barang ke } \\
\text { gudang }\end{array}$ & 5 & $\begin{array}{l}\text { Melakukan perhitungan dan } \\
\text { pencocokan data produksi dan } \\
\text { stock gudang }\end{array}$ & 4 & 80 \\
\hline & & \multicolumn{3}{|c|}{ RATA-RATA } & 5 & & 5 & & 4,5 & 112,5 \\
\hline
\end{tabular}

Dari tabel 8 diketahui nilai RPN dari tiap risiko dan juga nilai rata-rata RPN dari Entity pada divisi produksi. Tiga urutan pertama Entity yang memiliki nilai rata-rata RPN teringgi terdapat pada risiko pada pengolahan fasilitas dengan nilai 230,93 di susul risiko pada proses produksi dengan nilai raya-rata RPN 217,60 kemudian pada urutan ke tiga di tempati risiko pada kinerja karyawan dengan nilai rata-rata RPN 197,60. Sementara Entity pada urutan keempat sampai ketujuh memliki nilai rata-rata RPN hampir sama yaitu 145,80 pada Entity customer relation, 144,38 pada Entity supplier relation, 142,22 pada Entity pengelolaan SDM dan 141,04 pada Entity Manajemen perusahaan sedangkan dua Entity terakhir yang memiliki nilai rata-rata RPN terendah dimiliki risiko pada sirkulasi bahan baku dengan nilai rata-rata RPN 112,5 dan yang terakhir risiko pada pengembangan teknologi dengan nilai rata-rata RPN 94,37.

Menurut susilo \& kaho (2017) dalam penentuan prioritas risiko atau nilai batas penanganan dapat di tentukan oleh kepala Tim atau oleh manajemen. Sehingga pada penelitian ini berdasarkan kesepakatan dengan pihak manajemen yang di jadikan sebagai nilai batas risiko adalah rata-rata dari nilai rata-rata RPN Entity sehingga dalam menentukan nilai batas risiko / nilai kritis di lakukan perhitungan yang di dapat dari jumlah rata-rata RPN dari Entity dibagi dengan jumlah Entity. Jika di gambarkan dengan rumus akan seperti pada rumus di bawah ini:

$$
\begin{aligned}
\text { Nilai batas / Nilai kritis } & =\frac{\sum R P N \text { rata-rata Entitiy }}{\text { jumlah Entitiy }} \\
& =\frac{1426,03}{9} \\
& =158,45
\end{aligned}
$$

\begin{tabular}{|c|c|c|c|c|}
\hline $\begin{array}{l}\text { Pengembangan } \\
\text { teknologi }\end{array}$ & 4,67 & 4,33 & 4,67 & 94,37 \\
\hline Supplier relation & 5,50 & 5,83 & 4,50 & 144,38 \\
\hline Customer relation & 5,40 & 5,00 & 5,40 & 145,80 \\
\hline Manajemen perusahaan & 5,33 & 5,67 & 4,67 & 141,04 \\
\hline Kinerja karyawan & 6,80 & 5,80 & 5,00 & 197,20 \\
\hline Pengelolaan SDM & 5,33 & 6,67 & 4,00 & 142,22 \\
\hline Proses produksi & 6,80 & 6,40 & 5,00 & 217,60 \\
\hline Sirkulasi bahan baku & 5,00 & 5,00 & 4,50 & 112,50 \\
\hline Jumlah & 52,00 & 51,37 & 42,57 & 1426,03 \\
\hline \multicolumn{4}{|c|}{ Nilai kritis } & 158,45 \\
\hline
\end{tabular}

Tabel 9. Nilai Kritis

\begin{tabular}{|c|c|c|c|c|}
\hline Entitiy & S & O & D & $\begin{array}{c}\text { Rata-rata RPN } \\
\text { entitiy }\end{array}$ \\
\hline Pengelolaan fasilitas & 7,17 & 6,67 & 4,83 & 230,93 \\
\hline
\end{tabular}

\section{B. Analisis risiko menggunakan metode FTA}

Pada tahap analisis risiko menggunakan metode Fault Tree Analysis (FTA) ini bertujuan untuk melakukan analisis akar penyebab risiko (Basic Event) dari Top event. Dalam penelitian ini penentuan top event Pada metode FTA, Entity yang memiliki nilai rata-rata RPN di atas nilai kritis akan di jadikan sebagai Top event. Sedangkan dalam penetuan sub event dan basic event di peroleh dari penyebab risiko (risk cause) dan juga melalui brainstorming dengan responden.

Setelah di lakukan perhitungan dan dapat dilihat pada tabel 9 bahwa batas nilai / nilai kritis sebesar 158,45. Setelah di ketahui nilai kritis maka dapat di ketahui terdapat tiga Entity yang memiliki nilai RPN di atas nilai kritis diantaranya risiko pada pengelolaan fasilitas dengan nilai rata-rata RPN 230,93, risiko pada proses produksi dengan rata-rata nilai RPN 217,60 dan risiko pada kinerja karyawan dengan nilai rata-rata RPN 197,20. Diagram FTA dari ketiga risiko tersebut dapat di lihat pada gambar 7 sampai 9.

Dari Fault Tree Analysis akan di lakukan perhitungan Probabilitas Kejadian dan Analisa Kuantitatif. Dalam penelitian ini untuk menentukan besaran angka kemungkinan terjadinya sebuah risiko dilakukan menggunakan metode Uniform distribution probability yaitu menganggap terjadinya sebuah kemungkinan risiko itu terjadi mempunyai probalitas yang sama 
sehingga kejadian puncak memiliki nilai sama dengan 1 atau nilai probabilitasnya sama dengan $100 \%$. Seperti contoh pada bagan FTA pada top event penyebab risiko kegagalan pengelolaan fasilitas di bawah ini:

$\begin{aligned}>\text { Gate A } & =\text { B U C U D } \\ \text { - } \mathrm{P}(\mathrm{B}, \mathrm{C}, \mathrm{D}) & =\frac{\text { Gate A }}{3} \\ \mathrm{P}(\mathrm{B}, \mathrm{C}, \mathrm{D}) & =0,333 \\ >\text { Gate } \mathrm{B} & =\mathrm{E} \mathrm{U} \mathrm{F} \\ \text { - } \mathrm{P}(\mathrm{E}, \mathrm{F}) & =\frac{P(\text { Gate } B)}{2} \\ \mathrm{P}(\mathrm{E}, \mathrm{F}) & =\frac{0,33}{2} \\ \mathrm{P}(\mathrm{E}, \mathrm{F}) & =0,167 \\ >\text { Gate } \mathrm{C} & =\mathrm{p} 1 \mathrm{U} \mathrm{p} 2\end{aligned}$

Gate A

$$
=\mathrm{BUCUD}
$$

$P(B, C, D)$

$$
3
$$

$=\mathrm{E} \mathrm{U} \mathrm{F}$

Gate B

$=\frac{P(\text { Gate } B)}{2}$

$=\frac{0,33}{2}$

$=\mathrm{p} 1 \mathrm{U} \mathrm{p} 2$

$$
\begin{aligned}
\text { - }(\mathrm{p} 1, \mathrm{p} 2) & =\frac{P(\text { Gate } C)}{2} \\
\mathrm{P}(\mathrm{p} 1, \mathrm{p} 2) & =\frac{0,333}{2} \\
\mathrm{P}(\mathrm{p} 1, \mathrm{p} 2) & =0,167 \\
\text { Gate } \mathrm{D} & =\mathrm{G} \mathrm{U} \mathrm{p3} \\
\text { - } \mathrm{P}(\mathrm{G}, \mathrm{p} 3) & =\frac{P(\text { Gate } D)}{2} \\
\mathrm{P}(\mathrm{G}, \mathrm{p} 3) & =\frac{0,333}{2} \\
\mathrm{P}(\mathrm{G}, \mathrm{p} 3) & =0,167
\end{aligned}
$$

Selanjutnya dilakukan sebuah Analisa Kualitatif dan Minimal Cut Set dengan prinsip aljabar bolean untuk mendapatkan risiko-risiko yang mengarah pada terjadinya sebuah Top event.

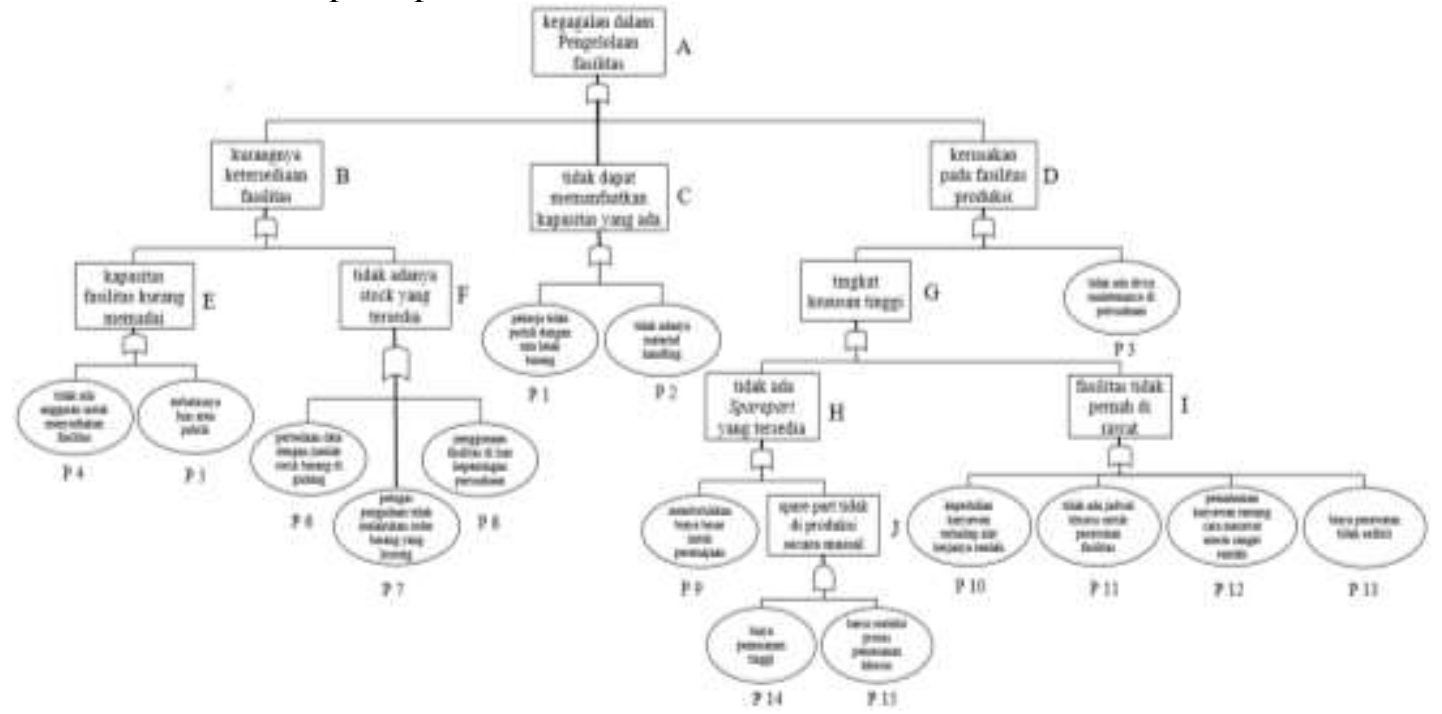

Gambar 7. Bagan FTA Risiko kegagalan pengelolaan fasilitas

Pada gambar 7 dapat di lihat bahwa Pada Top event Kegagalan pengelolaan fasilitas terdapat 15 basic event antara lain:

$>$ pekerja tidak peduli dengan tata letak barang (p1) dengan nilai probabilitas 0,167

$>$ tidak adanya material handling (p2) dengan nilai probabilitas 0,167

$>$ tidak ada divisi maintenance di perusahaan (p3) dengan nilai probabilitas 0,167

$>$ tidak ada anggaran untuk menyediakan fasilitas (p4) dengan nilai probabilitas 0,083

$>$ terbatasnya luas area pabrik (p5) dengan nilai probabilitas 0,083

$>$ perbedaan data dengan jumlah stock barang di gudang (p6) dengan nilai probabilitas 0,056

$>$ petugas pengadaan tidak melakukan order barang yang kosong (p7) dengan nilai probabilitas 0,056 penggunaan fasilitas di luar kepentingan perusahaan (p8) dengan nilai probabilitas 0,056

membutuhkan biaya besar untuk peremajaan (p9) dengan nilai probabilitas 0,042

- kepedulian karyawan terhadap alat kerjanya rendah (p10) dengan nilai probabilitas 0,021

$>$ tidak ada jadwal khusus untuk perawatan fasilitas (p11) dengan nilai probabilitas 0,021

$>$ pemahaman karyawan tentang cara merawat mesin sangat rendah (p12) dengan nilai probabilitas 0,021

$>$ biaya perawatan tidak sedikit (p13) dengan nilai probabilitas 0,021

biaya pemesanan tinggi (p14) dan harus melalui proses pemesanan khusus (p15) dengan nilai probabilitas 0,042

Dari 15 basic event yang 13 diantaranya merupakan kategori cut set yaitu: p1, p2, p3, p4, p5, p6, p7, p8, p9, p10, p11, p12, p13. 


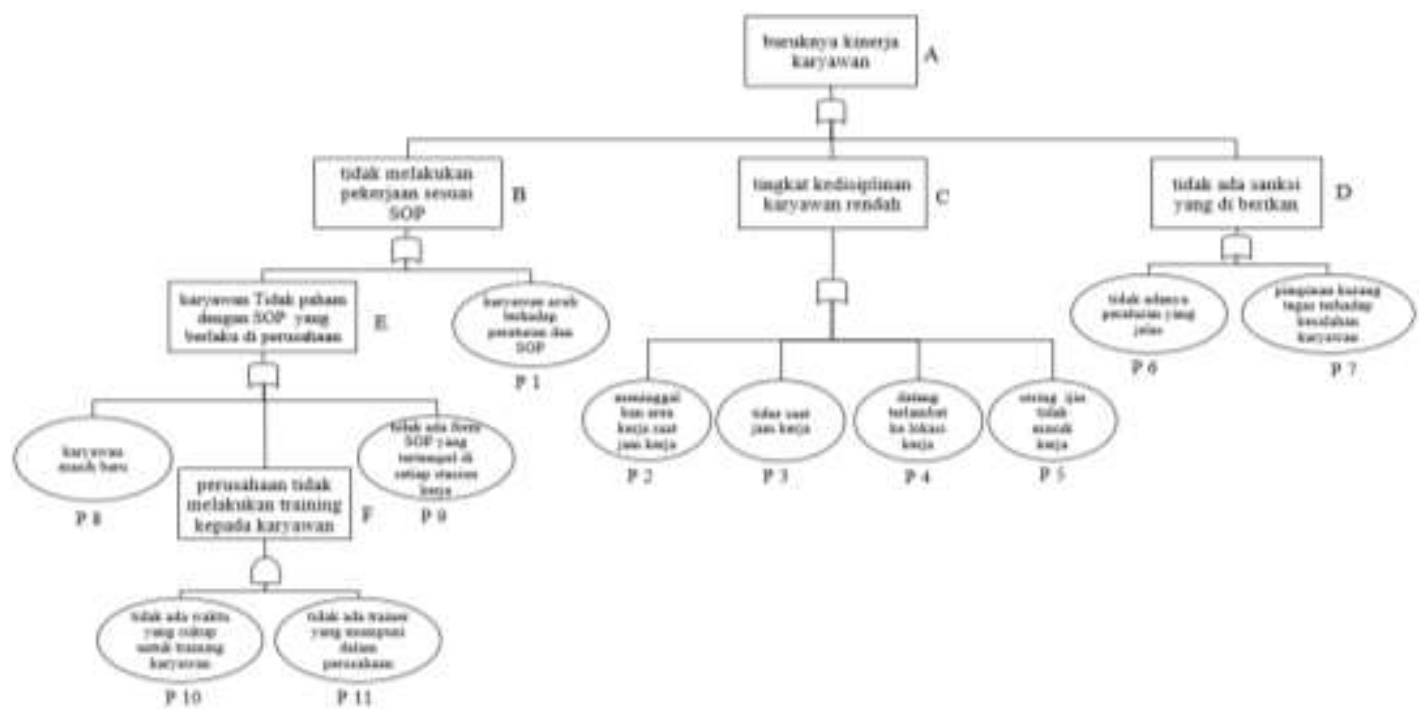

Gambar 8. Bagan FTA Risiko buruknya kinerja karyawan

Pada Top event Buruknya kinerja karyawan terdapat 11 basic event antara lain:

$>$ karyawan acuh terhadap peraturan dan SOP (p1) dengan nilai probabilitas 0,167

$>$ meninggalkan area kerja saat jam kerja (p2) dengan nilai probabilitas 0,083

$>$ tidur saat jam kerja (p3) dengan nilai probabilitas 0,083

$>$ datang terlambat ke lokasi kerja (p4) dengan nilai probabilitas 0,083

$>$ sering ijin tidak masuk kerja (p5) dengan nilai probabilitas 0,083

$>$ tidak adanya peraturan yang jelas (p6) dengan nilai probabilitas 0,167 pimpinan kurang tegas terhadap kesalahan karyawan (p7) dengan nilai probabilitas 0,163

> karyawan masih baru (p8) dengan nilai probabilitas 0,056

tidak ada form SOP yang tertempel di setiap stasiun kerja (p9) dengan nilai probabilitas 0,056

tidak ada waktu yang cukup untuk training karyawan (p10) dan tidak ada trainer yang mumpuni dalam perusahaan (p11) dengan nilai probabilitas 0,056

Dari 11 basic event yang terdapat pada bagan FTA risiko buruknya kinerja karyawan 9 diantaranya merupakan kategori cut set yaitu: p1, p2, p3, p4, p5, p6, p7, p8, p9.

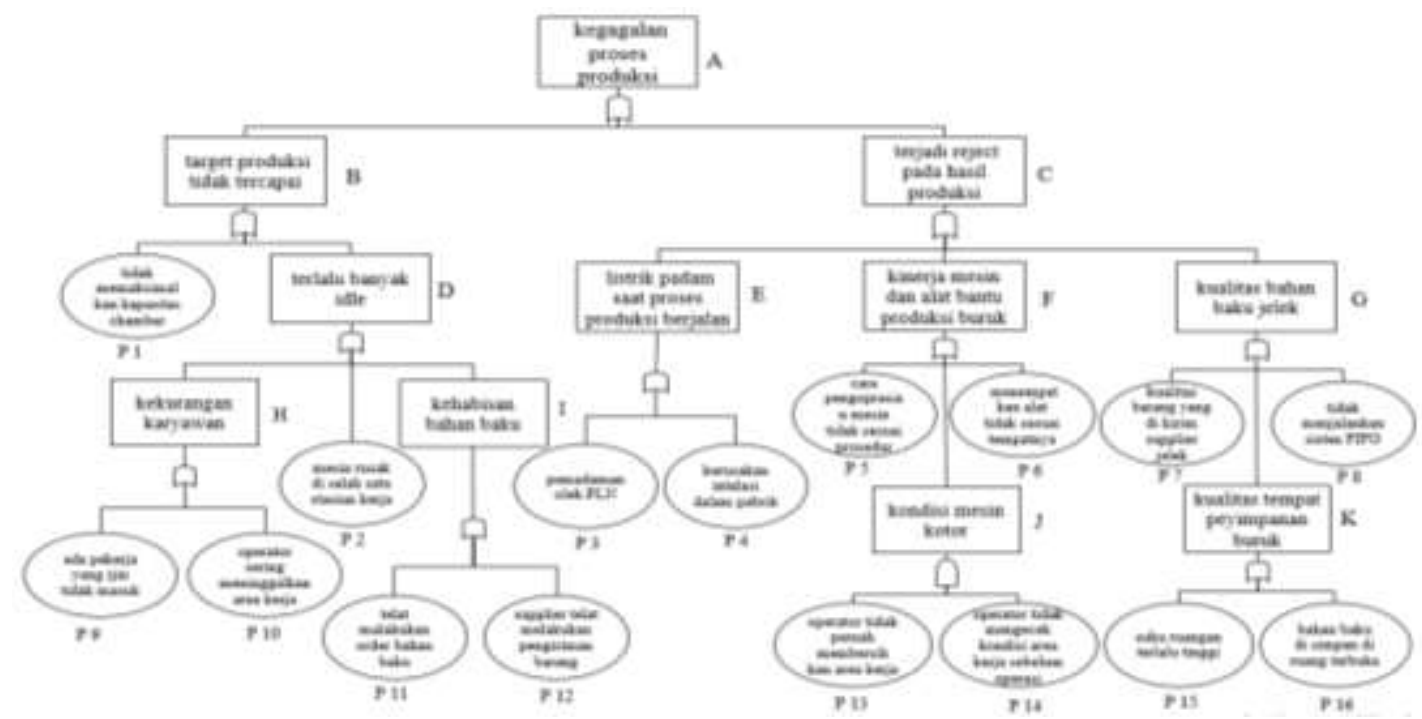

Gambar 9. Bagan FTA Risiko proses produksi

Top event Kegagalan dalam proses produksi terdapat 16 basic event antara lain: tidak bisa memaksimalkan kapasitas chamber (p1) dengan nilai probabilitas 0,25 
mesin rusak di salah satu stasiun kerja (p2) dengan nilai probabilitas 0,083

$>$ pemadaman oleh PLN (p3) dengan nilai probabilitas 0,083

$>$ kerusakan intalasi dalam pabrik (p4) dengan nilai probabilityas 0,083

$>$ cara pengoprasian mesin tidak sesuai prosedur (p5) dengan nilai probabilitas 0,056

$>$ menempat kan alat tidak sesuai tempatnya (p6) dengan nilai probabilitas 0,056

$>$ kualitas barang yang di kirim supplier jelek (p7) dengan nilai probabilitas 0,056

$>$ tidak menjalankan sisten FIFO (p8) dengan nilai probabilitas 0,056

$>$ ada pekerja yang ijin tidak masuk (p9) dengan nilai probabilitas 0,042

$>$ operator sering meninggalkan area kerja (p10) dengan nilai probabilitas 0,042

$>$ telat malakukan order bahan baku (p11) dengan nilai probabilitas 0,042

$>$ supplier telat melakukan pengiriman barang (p12) dengan nilai probabilitas 0,042

$>$ operator tidak pernah membersihkan area kerja (p13) dan operator tidak mengecek kondisi area kerja sebelum operasi (p14) dengan nilai probabilitas 0,056

$>$ suhu ruangan terlalu tinggi (p15) dengan nilai probabilitas 0,0278

$>$ bahan baku di simpan di ruang terbuka (p16) dengan nilai probabilitas 0,0278
Dari 16 basic event yang 14 diantaranya merupakan kategori cut set yaitu: p1, p2, p3, p4, p5, p6, p7, p8, p9, p10, p11, p12, p15, p16

Setelah di lakukan analisis kualitatif dan kuantitatif pada Entity maka hasil analisis ini akan dijadikan sebagai bahan pertimbangan dalam menentukan risk treatment dan mitigasi risiko.

\subsection{Perlakuaan Risiko (Risk treatment) dan Risk Response Planning}

Diklakukannnya perlakukan terhadap risiko bertujuan untuk menangani risiko yang ada dengan sebaik-baiknya serta mempertimbangkan semua alternatif solusinya dengan cara menganalisis dan menginterpretasi risiko berdasarkan hasil pengolahan data yang di peroleh. Risk treatment pada penelitian ini di dasarkan pada nilai kritis sebuah risiko yang bertujuan untuk memberikan prioritas treatment terhadap sebuah risiko sehingga dapat di harapkan langkah bisa efektif dalam mengatatasi risiko yang ada pada divisi produksi. Treatment risiko yang di pilih lebih kepada Risk Mitigation (mengurangi kemungkinan risiko) risk avoidance (menghindari risiko), Risk treatment usulan akan di jelaskan pada tabel 10.

Tabel 10. Risk treatment usulan

\begin{tabular}{|c|c|c|c|c|c|c|}
\hline \multirow{2}{*}{$\begin{array}{c}\text { Proses } \\
\text { bisnis }\end{array}$} & \multirow{2}{*}{ Entity } & \multirow{2}{*}{ ID } & \multirow{2}{*}{ Risk } & \multirow{2}{*}{ Treatment awal } & \multicolumn{2}{|c|}{ Risk treatment ususlan } \\
\hline & & & & & Risk Avoidance (menghindari risiko) & Risk Mitigation (mengurangi kemungkinan risiko) \\
\hline \multirow{6}{*}{$\begin{array}{c}\text { Kegagalan } \\
\text { internal }\end{array}$} & \multirow{6}{*}{$\begin{array}{l}\text { Pengelolaan } \\
\text { fasilitas }\end{array}$} & R1 & $\begin{array}{l}\text { Kapasitas } \\
\text { gudang tidak } \\
\text { mampu } \\
\text { menampung } \\
\text { barang yang ada }\end{array}$ & $\begin{array}{l}\text { Menempatkan } \\
\text { sebagian bahan } \\
\text { baku ke lokasi } \\
\text { produksi }\end{array}$ & $\begin{array}{l}\text { Membuat jadwal pemesanan bahan baku } \\
\text { dengan mempertimbangkan jumlah } \\
\text { permintaan dan juga kapasitas gudang }\end{array}$ & \\
\hline & & R2 & $\begin{array}{l}\text { Kerusakan pada } \\
\text { mesin } \\
\text { kompressor } \\
\text { sehingga } \\
\text { tekanan angin } \\
\text { melemah }\end{array}$ & $\begin{array}{l}\text { Melakukan } \\
\text { pengecekan kondisi } \\
\text { mesin kompresor } \\
\text { setiap hari }\end{array}$ & $\begin{array}{l}\text { Membuat jadwal perawatan dan juga } \\
\text { memanggil teknisi secara periodik untuk } \\
\text { melakukan pengecekan kondisi kompressor } \\
\text { secara menyeluruh }\end{array}$ & \\
\hline & & R3 & $\begin{array}{l}\text { Lampu } \\
\text { penerang redup } \\
\text { / padam }\end{array}$ & $\begin{array}{l}\text { Mengganti lampu } \\
\text { yang sudah redup } \\
\text { dengan lampu yang } \\
\text { baru }\end{array}$ & Menyediakan safety stock lampu & \\
\hline & & R4 & $\begin{array}{l}\text { Jumlah dan } \\
\text { kapasitas mesin } \\
\text { minim }\end{array}$ & $\begin{array}{l}\text { Menambah jam } \\
\text { lembur }\end{array}$ & & $\begin{array}{l}\text { Mengatur jadwal produksi agar dapat produksi } 24 \text { ban } \\
\text { dalam sekali chamber dan mengatur jam keluar masuk } \\
\text { produk kedalam chamber agar dapat di gunakan } 3 \text { kali } \\
\text { dalam } 1 \text { hari kerja }\end{array}$ \\
\hline & & R5 & $\begin{array}{l}\text { AC dalam } \\
\text { gudang tread } \\
\text { dan gum rusak }\end{array}$ & $\begin{array}{l}\text { Melakukan } \\
\text { pengecekan suhu } \\
\text { ruangan dan juga } \\
\text { AC secara berkala } \\
\end{array}$ & $\begin{array}{l}\text { Menambah kuantitas AC atau mengganti } \\
\text { dengan AC yang baru }\end{array}$ & \\
\hline & & R6 & $\begin{array}{l}\text { Listrik tiba-tiba } \\
\text { padam }\end{array}$ & $\begin{array}{l}\text { Mengecek kondisi } \\
\text { intalasi listrik } \\
\text { sekitar area kerja } \\
\text { sebelum melakukan } \\
\text { pekerjaan }\end{array}$ & & $\begin{array}{l}\text { Membuat jadwal khusus untuk melakukan pengecekan } \\
\text { secara keseluruhan dan selalu mencari informasi tentang } \\
\text { pemadaman listrik PLN }\end{array}$ \\
\hline \multirow{2}{*}{$\begin{array}{l}\text { Kegagalan } \\
\text { human }\end{array}$} & \multirow{2}{*}{$\begin{array}{c}\text { Kinerja } \\
\text { karyawan }\end{array}$} & R24 & $\begin{array}{l}\text { Salah dalam } \\
\text { pemberian label } \\
\text { produksi }\end{array}$ & $\begin{array}{l}\text { Instruksi kepada } \\
\text { karyawan inspeksi } \\
\text { untuk melakukan } \\
\text { malakukan } \\
\text { pengecekan label } \\
\text { produksi } \\
\end{array}$ & & $\begin{array}{l}\text { Memberikan instruksi kepada seluruh karyawan untuk } \\
\text { mengecek label dan memberikan teguran kepada } \\
\text { karyawan jika proses pengerjaaan tidak sesuai label }\end{array}$ \\
\hline & & R25 & $\begin{array}{l}\text { Tidak } \\
\text { menambal cacat } \\
\text { lubang pada } \\
\text { bodi ban }\end{array}$ & $\begin{array}{l}\text { Instruksi pada } \\
\text { karyawan bagian } \\
\text { building untuk } \\
\text { melakukan } \\
\text { pengecekan } \\
\text { kebocoran ban } \\
\end{array}$ & & $\begin{array}{l}\text { Melakukan pengecekan kondisi produk sebelum masuk } \\
\text { chamber serta memberikan teguran kepada karyawan jika } \\
\text { ada produk dengan lubang tembus yang tidak di tabal }\end{array}$ \\
\hline $\begin{array}{l}\text { Kegagalan } \\
\text { human }\end{array}$ & $\begin{array}{c}\text { kinerja } \\
\text { karyawan }\end{array}$ & R26 & $\begin{array}{l}\text { Salah dalam } \\
\text { memberi tanda } \\
\text { cacat }\end{array}$ & $\begin{array}{l}\text { Mengawasi kinerja } \\
\text { pekerja secara } \\
\text { maksimal }\end{array}$ & & $\begin{array}{l}\text { Melakukan pengawasan terhadap kinerja karyawan bagian } \\
\text { inspeksi serta memberikan teguran jika terjadi kesalahan }\end{array}$ \\
\hline
\end{tabular}




\begin{tabular}{|c|c|c|c|c|c|c|}
\hline & & R27 & $\begin{array}{l}\text { Karyawan tidak } \\
\text { melakukan } \\
\text { pekerjaan sesuai } \\
\text { SOP }\end{array}$ & $\begin{array}{l}\text { Memberikan } \\
\text { training kepada } \\
\text { karyawan sesuai } \\
\text { dengan jobdisk } \\
\end{array}$ & & $\begin{array}{l}\text { Selain memberikan training kepada karyawan agar paham } \\
\text { SOP semestinya juga melakukan briefing setiap hari } \\
\text { sebelum melakukan pekerjaan }\end{array}$ \\
\hline & & R28 & $\begin{array}{l}\text { Keterbatasan } \\
\text { skill karyawan }\end{array}$ & $\begin{array}{l}\text { Memberikan } \\
\text { training kepada } \\
\text { karyawan }\end{array}$ & & $\begin{array}{l}\text { Memberikan training kepada karyawan serta melakukan } \\
\text { pendampingan kepada karyawan sampai dirasa sudah bisa } \\
\text { dan lancar dalam melakukan pekerjaannya }\end{array}$ \\
\hline \multirow{5}{*}{$\begin{array}{c}\text { kegagalan } \\
\text { proses }\end{array}$} & \multirow{5}{*}{$\begin{array}{c}\text { proses } \\
\text { produksi }\end{array}$} & R32 & $\begin{array}{l}\text { Tread tidak } \\
\text { dapat merekat } \\
\text { sempurna } \\
\text { dengan body } \\
\text { ban }\end{array}$ & $\begin{array}{l}\text { Pengecekan kualitas } \\
\text { chuisen gum } \\
\text { sebelum di gunakan }\end{array}$ & & $\begin{array}{l}\text { Karyawan bagian filling harus selalu melakukan } \\
\text { penegcekan kualitas sebelum gum sebelum di gunakan } \\
\text { serta melakukan pengecekan rutin suhu ruangan gudang } \\
\text { saat mengambil gum di gudang }\end{array}$ \\
\hline & & R33 & $\begin{array}{l}\text { Terjadi } \\
\text { kerusakan } \\
\text { mesin pada saat } \\
\text { proses produksi }\end{array}$ & $\begin{array}{l}\text { Melakukan } \\
\text { pelumasan sebelum } \\
\text { memulai kerja dan } \\
\text { memperbaiki mesin } \\
\text { jika rusak } \\
\end{array}$ & & $\begin{array}{l}\text { Memberikan edukasi kepada operator tentang cara } \\
\text { menangani mesin rusak serta perawatan mesin yang baik } \\
\text { dan benar }\end{array}$ \\
\hline & & R34 & Envelope bocor & $\begin{array}{l}\text { Melakukan } \\
\text { pengecekan kondisi } \\
\text { envolope sebelum di } \\
\text { gunakan }\end{array}$ & $\begin{array}{l}\text { Karyawan bagian pemasangan envelope } \\
\text { harus melakukan pengecekan kondisi } \\
\text { envelope sebelum di gunakan dan kepala } \\
\text { bagian harus mengganti envelope yang } \\
\text { sudah habis masa pakai }\end{array}$ & \\
\hline & & R35 & $\begin{array}{l}\text { Ban dalam } \\
\text { bocor }\end{array}$ & $\begin{array}{l}\text { Melakukan } \\
\text { pengecekan kondisi } \\
\text { ban dalam sebelum } \\
\text { di gunakan }\end{array}$ & $\begin{array}{l}\text { Karyawan bagian pemasangan envelope } \\
\text { harus melakukan pengecekan kondisi } \\
\text { envelope sebelum di gunakan dan kepala } \\
\text { bagian harus mengganti ban dalam yang } \\
\text { sudah habis masa pakai }\end{array}$ & \\
\hline & & R36 & $\begin{array}{l}\text { Hasil produksi } \\
\text { tidak bisa } \\
\text { matang } \\
\text { sempurna }\end{array}$ & $\begin{array}{l}\text { Melakukan } \\
\text { pengecekan kondisi } \\
\text { chamber sebelum } \\
\text { memasukkan } \\
\text { produk dan setelah } \\
\text { mengeluarkan } \\
\text { produk dari } \\
\text { chamber }\end{array}$ & & $\begin{array}{l}\text { Membuat jadwal khusus untk melakukan perawatan } \\
\text { chamber serta melakukan penegcekan kondisi suhu } \\
\text { maksimal } 1 \text { jam sekali }\end{array}$ \\
\hline
\end{tabular}

Pada tabel 10 dapat ketahui bahwa terdapat 6 risiko (Risk Avoidance) dengan treatment usulan untuk menhindari risiko serta 10 risiko dengan treatment usulan untuk mengurangi kemungkinan terjadinya risiko (Risk Mitigation).

Selain memberikan treatment usulan penulis juga memberikan Risk response planning dengan tujuan untuk menetukan cara bagaimana divisi produksi harus bereaksi terhadap risiko yang telah dianalisa. Dengan banyaknya basic event yang terdapat pada entitiy yang memliki nilai RPN di atas nilai kritis, Untuk melaksnakan Risk response planning pihak manajemen dapat mengambil kebijakan membentuk kepala bagian dalam setiap kegiatan yang menunjang kegiatan divisi produksi. Pembentukan ini di maksudkan dengan tujuan mempermudah tugas untuk mengelola dan merawat fasilitas, pengawasan kinerja karyawan dan proses produksi serta pengawasan kualitas produk. Kepala bagian yang dibutuhkan divisi produksi yaitu kepala regu produksi, staf bagian kualitas, dan staf bagian maintenance (perawatan). Berikut ini struktur organisasi saat ini dan usulan struktur organisasinya.

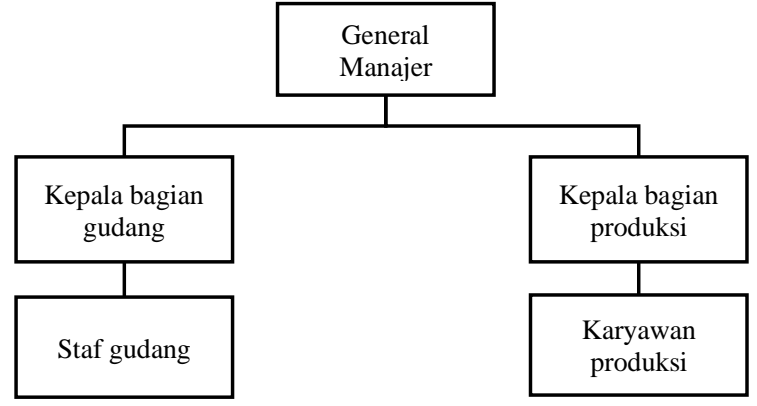

Gambar 10. Struktur organisasi saat ini Sumber: CV. Citra Buana Mandiri

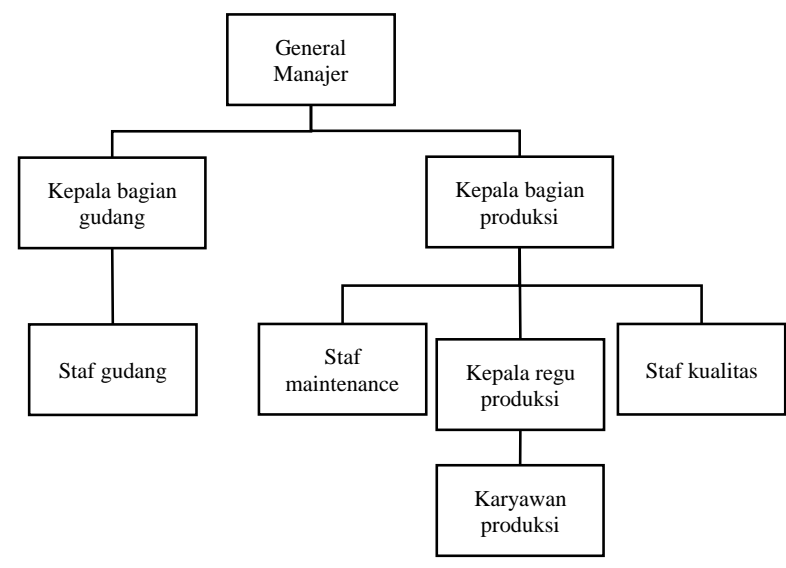

Gambar 11. Struktur organisasi usulan

Berdasarkan struktur organisasi usulan akan dapat tentukan risk respons planning pada divisi produksi sebagai berikut:

1) Kepala bagian produksi akan sangat terbantu dengan adanya staf maintenance, staf kualitas dan kepala regu produksi untuk mengantisipasi terjadinya risiko serta melakukan evaluasi terhadap risiko pada divisi produksi sehingga bisa lebih fokus 
dalam laporan pertanggung jawaban setiap kegiatan divisi produksi kepada general manajer dan juga koordinasi dengan divisi lain.

2) Dengan adanya kepala regu produksi proses pengawasan terhadap kinerja karyawan dan dapat menjadi mentor bagi karyawan yang masih membutuhkan pelatihan dalam menjalankan proses produksi terutama karyawan baru. Serta dapat membantu kelancaran kegiatan proses produksi.

3) Dengan adanya staf maintenance akan memiliki sesorang ahli dan fokus untuk membantu proses perawatan fasilitas yang berhubungan dengan divisi produksi sehingga perusahaan tidak perlu lagi memanggil teknisi untuk merawat dan memperbaiki fasilitas dan kendala fasilitas yang dapat memepengaruhi kinerja divisi produksi bisa segera ditangani.

4) Dengan adanya staf kualitas akan ada jaminan kualitas row material sebelum masuk proses produksi serta jaminan kualitas produk jadi yang akan di kirim ke customer.

\section{Kesimpulan}

Dari hasil penelitian dengan menggunakan pendekatan risk management berbasis ISO 31000 dengan metode FMEA dan FTA dapat disimpulkan sebagai berikut:

1) Teridentifikasi unsur risiko yang mempunyai nilai RPN tertinggi berdasarkan beberapa sub indicator yang ada sebagai berikut:

* Pada pendekatan FMEA dengan melakukan wawancara dan brainstorming dengan pihak responden dari pihak manajemen terdapat 38 kejadian risiko dengan 6 risiko dari pengelolaan fasilitas, 3 risiko dari pengembangan teknoloi, 5 risiko dari customer relation, 6 risiko dari supplies relation, 3 risiko dari Manajemen perusahaan, 5 resiko dari kinerja karyawan, 3 risiko dari pengelolaan SDM, 5 risiko dari proses produksi, dan 2 risiko dari sirkulasi bahan baku.

* Dari beberapa resiko yang ada dalam setiap Entitiy yang mempunyai nilai ratarata RPN di atas nilai kritis yang di tetapkan sehingga membutuhkan penanganan lebih adalah pada Entitiy pengelolaan fasilitas dengan nilai rata-rata RPN 230, 93 proses produksi dengan nilai rata- rata RPN 217,60 serta kinerja karyawan dengan nilai rata-rata RPN 197,20 .
2) Pada pendekatan dengan metode FTA dengan Entitiy yang melebihi nilai kritis sebagai Top event teridentifikasi akar penyebab (sub event) risiko risiko yang berpengaruh terhadap operasional perusahaan sebagai berikut:

* Pada risko dalam pengelolaan fasilitas terdapat 12 basic event di mana 10 diantaranya merupakan kategori cut set yaitu: tidak ada anggaran untuk menyediakan fasilitas, perbedaan data dengan jumlah stock barang di gudang, petugas pengadaan tidak melakukan order barang yang kosong, penggunaan fasilitas di luar kepentingan perusahaan, membutuhkan biaya besar untuk peremajaan, kepedulian karyawan terhadap alat kerjanya rendah, tidak ada jadwal khusus untuk perawatan fasilitas, pemahaman karyawan tentang cara merawat mesin sangat rendah, biaya perawatan tidak sedikit,

* Risiko pada kinerja karyawan terdapat 9 basic event yang 7 di antaranya merupakan kategori cut set yaitu: pimpinan kurang tegas terhadap kesalahan karyawan, karyawan masih baru, tidak ada form SOP yang tertempel di setiap stasiun kerja, meninggalkan area kerja saat jam kerja, tidur saat jam kerja, datang terlambat ke lokasi kerja, sering ijin tidak masuk kerja.

* Risiko pada proses produksi terdapat 16 basic event yang 14 diantaranya merupakan kategori cut set yaitu : tidak bisa memaksimalkan kapasitas chamber, mesin rusak di salah satu stasiun kerja, pemadaman oleh PLN, kerusakan intalasi dalam pabrik, cara pengoprasian mesin tidak sesuai prosedur, menempat kan alat tidak sesuai tempatnya, kualitas barang yang di kirim supplier jelek, tidak menjalankan sisten FIFO, ada pekerja yang ijin tidak masuk, operator sering meninggalkan area kerja, telat malakukan order bahan baku, supplier telat melakukan pengiriman barang, suhu ruangan terlalu tinggi, bahan baku di simpan di ruang terbuka.

3) Perlakuan risiko (risk treatment) yang jadi bahan pertimbangan adalah hasil dari nilai Risk priority number rata-rata pada Entity yang lebih besar dari nilai kritis , serta analisis efektifitas risk treatment 
kondisi awal . Risk treatment usulan mengurangi dampak risiko (risk mitigation) dilakukan pada R4, R6, R24, R25, R26, R27, R28, R32, R33,R36 dan Risk treatment usulan menghindari risiko (risk avoidance) dilakukan pada R1, R2, R3, R5, R34, R35. Untuk Risk response planning pihak manajemen dapat mengambil kebijakan membentuk kepala bagian dengan tujuan mempermudah tugas untuk mengelola dan merawat fasilitas serta pengawasan kinerja karyawan produksi. Kepala bagian yang dibutuhkan divisi produksi yaitu kepala regu produksi, staf bagian kualitas, dan staf bagian maintenance (perawatan).

\section{Daftar Pustaka}

Abisay, T. G., \& Nurhadi. (2013). Manajemen Risiko Berbasis ISO 31000 Pada Bandara Soekarno Hatta. Jurnal Teknik Industri, Vol. 14, No. 2, PP 116-130.

Alijoyo, A. (2006). Enterprise Risk Manajemen, Jakarta: Ray Indonesia.

Ansori, N. \& Mustajib, M. I. (2013). Sistem Perawatan Terpadu (Integrated Maintenance System). Yogyakarta: Graha ilmu.

Bahari, H., Leksono, E. B., \& Ismiyah, E. (2018). Pendekatan Risk Management \& Analisis SWOT Untuk Mengantisipasi Penurunan Laba di Ecos Minimart Gresik. Jurnal Matrik, Vol. XVIII, No. 2, PP 23-40.

Gaspersz, V. (2002). Pedoman implementasi program Six Sigma terintegrasi dengan ISO 9001:2000, MBNQA, dan HACCP. Jakarta: Gramedia Pustaka Utama.

Hanafi, Mamduh. (2006). Manajemen Risiko (Edisi Pertama). Yogyakarta: Unit Penerbit dan Perctakan Sekolah Tinggi Ilmu Manajemen YKPN.

International Standard. (2009). ISO 31000: Risk Management-Principles and Guidelines. Geneva: ISO.

Kristyanto, R., Sugiono., \& Yuniarti, R. (2015). Analisis risiko operasional pada proses produksi gula dengan menggunakan metode Multi Attribute Failure Mode Analisys (MAFMA) (studi kasus: $P G$ Kebun Agung Malang). Jurnal Rekayasa dan Manajemen Sistem Industri, Vol. 3, No. 3, PP 592-601.

Rosih, A. R., Choiri, M., \& Yuniarti, R. (2015). Analisis Risiko Operasional Pada Departemen Logistik Dengan Menggunakan Metode FMEA. Jurnal Rekayasa dan Manajemen Sistem Industri, Vol. 3, No. 3, PP 580-591.

Saifuddin, M. H., Sugiono., \& Yuniarti, R. (2014). Analisis Risiko Operasional pada Divisi Bengkel PT. XYZ Branch Official Malang. Jurnal Rekayasa dan Manajemen Sistem Industri, Vol. 2, No. 2, PP 240-250.

Siregar, H. F., \& Parinduri, I. (2017). Protoype Gerbang Logika (AND, OR, NOT, NAND, NOR) Pada Laboratorium Elektronika STMIK Royal Kisaran. Jurnal Teknologi Informasi (jur TI), Vol. 1, No. 1, PP 37-47.

Sunanto, A., Estrianto, Y., \& Harjanto, B. (2013). Analisis Cacat Produk ban Vulkanisir Jenis Truk dan Bus Pada CV. Sigma Jaya Surakarta. Jurnal ilmiyah pendidikan teknik mesin, Vol. 1, No. 4.

Susilo, L. J. \& Kaho, V. R. (2017). Manajemen Risiko Berbasis ISO 31000. Jakarta pusat: PPM.

Susilo, L. J. \& Kaho, V. R. (2019). Manajemen Risiko Berbasis ISO 31000:2018. Jakarta: PT Grasindo.

Hidayat, H., Jufriyanto, M., \& Rizqi, A. (2021). Perancangan RCM (Reliability Centered Maintenance) Untuk Mengurangi Downtime Mesin Pembuat Botol (Studi Kasus PT IGLAS (Persero), Gresik). MATRIK : Jurnal Manajemen Dan Teknik Industri Produksi, 21(2), 157 - 164. doi:10.30587/matrik.v21i2.2038

Hidayat, H., Jufriyanto, M., \& Rizqi, A. (2020). ANALISIS OVERALL EQUIPMENT EFFECTIVENESS (OEE) PADA MESIN CNC CUTTING. ROTOR, 13(2), 61-66. doi:10.19184/rotor.v13i2.20674 